\title{
Japan and the Asian Economies: A "Miracle" in Transition
}

ONE EAST ASIAN country after another has taken off from a stagnant state to achieve an annual economic growth rate of 10 percent or more. The fact that such high economic growth rates are being sustained, along with observation based on growth convergence regressions that prior economic and social conditions do not seem to have warranted such rapid growth, has led many to call the East Asian growth a miracle. ${ }^{\prime}$

However, this is not the first time that an Asian country has grown miraculously fast. From the mid-1950s until 1973, Japan grew at a rate comparable to that of the East Asian economies today. And just as concerns are voiced today that some East Asian economies are overheating and their governments face the difficult task of inducing a "softlanding," a similar concern was heard in Japan three decades ago.

Japan's high rate of growth from the mid-1950s through the early 1970 s was a topic explored by many studies at the time. Several authors believed that Japan's economic institutions and policies were unique, and that its growth was an exception to the rule. In light of the rapid growth of the other East Asian economies in recent years, this earlier Japanese experience is no longer viewed as exceptional. The success of the East Asian economies offers fresh case studies for development economics and growth theory. The World Bank study The East Asian

The views expressed are those of the author and should not be interpreted as representative of the staff or trustees of the Brookings Institution or the International Monetary Fund. David Weinstein offered constructive comments and helpful suggestions for revising the paper. The comments of other participants at the Brookings Panel meeting, in particular, Jeffrey Frankel, Edward Lincoln, and Yung Chul Park, were also very helpful. Tokuo Iwaisako provided excellent research assistance.

1. See, for example, World Bank (1993), Page (1994), Easterly (1995), and Campos and Root (1996). 
Miracle is one of the most comprehensive analyses of growth in the region. ${ }^{2}$ New growth theory and growth convergence regressions have been applied to test for the sources of this growth. With scale economies in such models, multiple equilibria are possible, leading some to stress the importance of a "big push" - simultaneous growth in many sectors-or various government interventions in the growth process. Such studies often emphasize the importance of initial conditions, including education, other aspects of social infrastructure, and political stability.

Rather than providing such a broad analysis based on growth theory, this paper looks closely at Japan's experience and the lessons it may provide. In the early postwar decades, Japan was recording annual growth rates of around 10 percent, and many academic and policy questions were related to how long high growth rates could be sustained. The high growth rates of the 1950s and 1960s were in part explained by Japan's quick recovery of the productive potential that had been destroyed during World War II. However, the economy had surpassed its prewar potential trend by the beginning of the 1960s, and it continued to grow rapidly throughout that decade and into the beginning of the 1970s. Indeed, at the height of the postwar miracle, Japan's real GDP expanded four fold in fifteen years, from 1958 to 1973.

The growth trend of the 1960s slowed abruptly after the first oil crisis, in 1973-74. But although the annual growth rate over 1975-90 was roughly half of that achieved in the previous two decades, it still exceeded 4 percent. Another interesting feature of this period was the sharp nominal appreciation of the yen: its value tripled from 1970 to 1995. Largely due to this currency appreciation, per capita GDP, denominated in U.S. dollars at the market exchange rate, had overtaken that of the United States by the late 1980s. Already by the mid-1980s, many observers were noting that the Japanese economy had matured, with per capita income approaching that of the leading industrial economies and growth slowing to approach rates in the leading industrial economies. Market forces, especially the sharp appreciation of the yen, had forced rapid structural changes in industry. Some special features of the Japanese economy, including some regulatory measures, disappeared, although others persisted. During the second half of the 1980s, the economy experienced a large speculative bubble in asset prices,

2. World Bank (1993). 
which then burst in the first half of the 1990s. The growth rate did not rise above 1 percent between 1992 and 1995.

Today, the Japanese economy merits research for two reasons. First, because the economy is taking much longer than expected to recover from the burst bubble, economists and policymakers in Japan are uncertain about the future growth of the economy. Second, as some of the East Asian economies are sustaining growth at rates that once were achieved by Japan, it is useful to look for similarities among them and lessons that can be learned. Here I address both of these issues. Using time-series data extending back more than a century, I first review different stages of Japanese economic development. Difficulties as well as successes are summarized, with particular emphasis on the problems of the 1990s and how they may be overcome. I then note some of the similarities and differences between the Japanese economy and the East Asian economies whose growth rates in the 1980s and 1990s rival the records set by Japan during the 1960s and 1970s. Finally, I draw some lessons for the East Asian economies, focusing especially on whether some of the difficulties that Japan has faced in the 1990s and earlier can be avoided by East Asian economies in the future.

\section{Japanese Economic Development: A Long-Run View}

The high economic growth rates of the 1960s and early 1970s in Japan stimulated much study at the time. ${ }^{3}$ Here, I start with a longer view of Japanese economic development based on time-series data from 1880 to the present. Figure 1 shows the time series of real GDP from 1880 to 1995 , and table 1 gives average growth rates for various subperiods. The Japanese economy expanded at an average annual rate of about 3 percent for more than a half century before the Second World War. This long period of sustained growth was accompanied by rapid structural change from an agrarian to an industrialized economy. The

3. Representative examples from the 1970s include Ohkawa and Rosovsky (1973), Patrick and Rosovsky (1976), Denison and Chung (1976a, 1976b), and Ohkawa and Shinohara (1979). Long-term statistics for various sectors, as well as aggregate variables, are collected in the fourteen volume series Estimates of Long-Term Economic Statistics of Japan since 1868, published between 1965 and 1990 under the general editorship of Kazushi Ohkawa, Miyohei Shinohara, and Mataji Umemura. 
Figure 1. Real GDP, Japan, 1880-1995a

Trillions of 1990 yen (logarithmic scale)

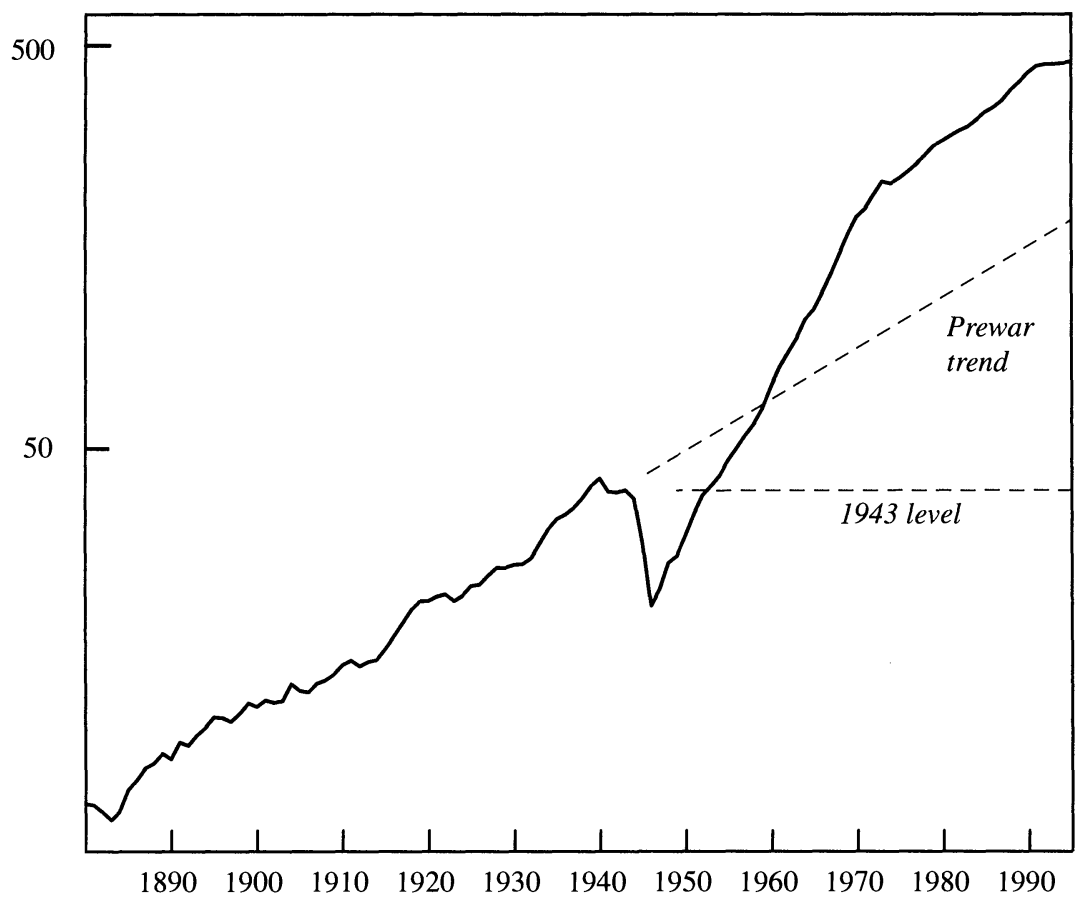

Source: Author's calculations. Data for 1880-85 are from Fujino (1975); for 1886-1940, from Ohkawa and Shinohara (1979); for 1941-55, from Ohkawa, Takamatsu, and Yamamoto (1974); and for 1956-95, from Japan, Economic Planning Agency (various years) (available on CD-ROM for 1996).

a. Prewar data are for GNP.

postwar economic achievement should be understood against this background. As productive resources were either diverted to military use or destroyed in war, real output fell by half from 1944 to 1946 . Recovery was quick, however. By the mid-1950s, GDP had regained its 1943 level, and by 1960, it was at the level predicted by its prewar trend. The following ten to fifteen years of high economic growth, in essence, represent the Japanese "miracle." This terminology stems from the fact that economists, using a Solow growth model and analyzing total factor productivity, could not explain the large Solow residuals that they found. ${ }^{4}$

4. See, for example, Denison and Chung (1976a, 1976b). 
Table 1. Real GDP Growth, Japan and the United States, Selected Subperiods ${ }^{a}$ Annual percentage rate

\begin{tabular}{lcc}
\hline Subperiod & Japan & United States \\
\hline $1890-1905$ & 2.65 & 3.86 \\
$1905-20$ & 3.49 & 2.85 \\
$1920-35$ & 3.18 & 1.29 \\
$1946-60$ & 9.38 & 3.45 \\
$1960-75$ & 8.26 & 3.81 \\
$1975-90$ & 4.12 & 2.96 \\
$1990-95$ & 1.28 & 1.89 \\
\hline
\end{tabular}

Source: Author's calculations. Data on Japan for 1880-85 are from Fujino (1975); for 1886-1935, from Ohkawa and Shinohara (1979); for 1946-55, from Ohkawa, Takamatsu, and Yamamoto (1974); for 1956-95, from Japan, Economic Planning Agency (various years) (available on CD-ROM for 1996). Data on the United States are from Friedman and Schwartz (1982) and the Economic Report of the President, 1996.

a. Prewar growth rates are for GNP growth.

Economists have debated possible reasons for the abrupt downward shift in the growth rate in 1973-74. Aside from the obvious argument that the Japanese economy must have converged to other industrial economies and that therefore opportunities for high-return investment had been exhausted, other factors, such as higher oil prices, pollution prevention regulations, and the appreciation of the yen, were considered. To the extent that the explanation of the high growth rates before 1973 was attributed to the model's residuals, the slowdown was not explained. That the slowdown was unexpected, and was not recognized for a long time, is clearly reflected in the fact that while the government's five-year target forecasts of growth rates had always been underestimates before 1973, they were overestimates from 1975 until the late 1980s. ${ }^{5}$ Japanese growth rates seem to have shifted downward again in the first half of the 1990s, a period investigated more fully below.

Real appreciation of the yen has been a distinctive feature of the Japanese economy in the postwar period. Figure 2 shows the behavior of the real exchange rate, defined as dollars to yen (the reciprocal of the yen-dollar rate) multiplied by the ratio of the Japanese consumer price index (CPI) to the U.S. CPI. Figure 3 presents Japan's relative per capita growth performance (that is, the Japanese per capita growth rate less the U.S. rate) and real exchange rate behavior for various subperiods before and after World War II. During each postwar sub-

5. See Ito (1992, pp. 66-67). The government's failure to recognize the downward shift in trend growth rates was a contributory factor of the excessive fiscal stimulus in the second half of the 1970s; see Ito (1992, ch. 6) and Asako, Ito, and Sakamoto (1991). 
Figure 2. Real Exchange Rate of the Yen, 1879-1995

$\log$ index $^{b}$

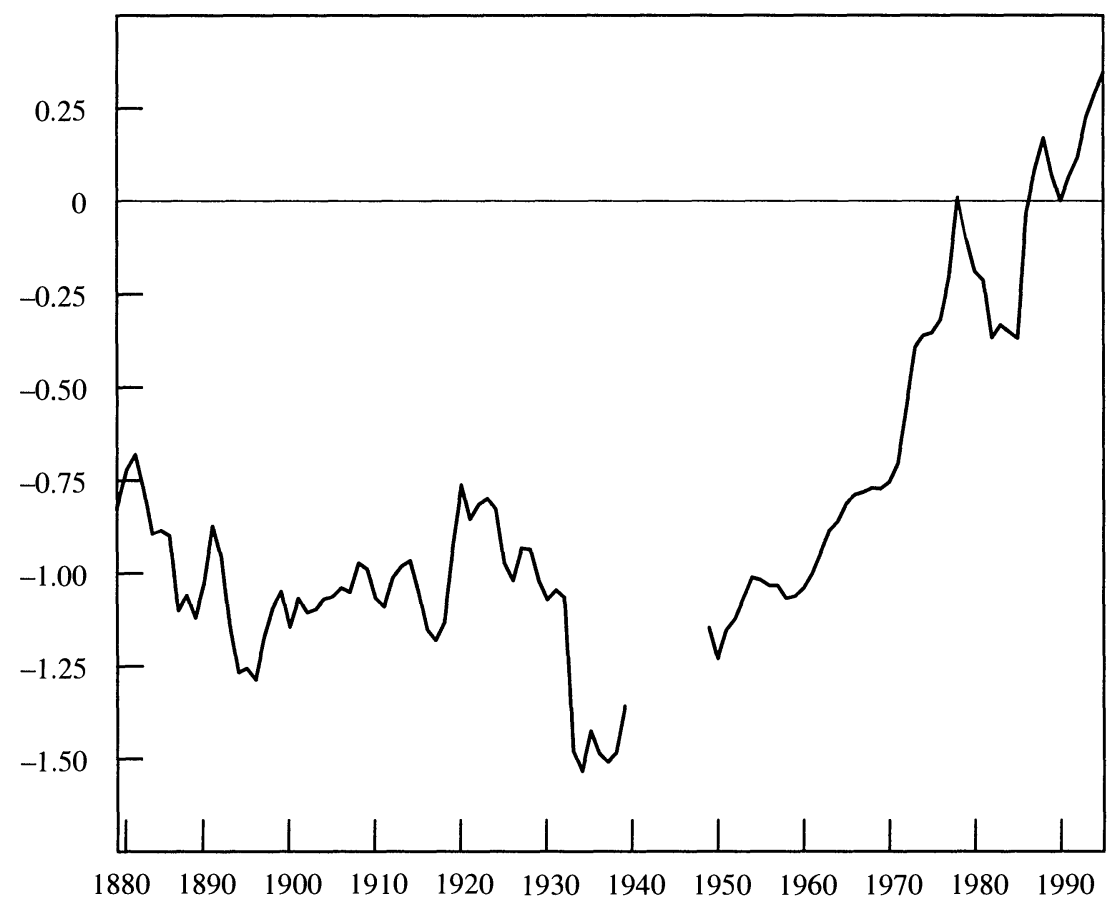

Source: Author's calculations. Data on the nominal exchange rate for 1879-1940 are from Yamazawa and Yamamoto (1979); for 1949-70, the Bretton Woods rate of 360; and for 1971-95, average of daily closing rates reported in Toyo Kezai Shimposha (1996). Data on consumer price indexes are from Ohkawa and others (1966); Japan, Management and Coordination Agency (1996); the Economic Report of the President, 1996; and provided directly by the National Bureau of Economic Research.

a. Throughout the paper, the real exchange rate of a country's currency is defined as the price of the local currency in dollars multiplied by the ratio of the local CPI to the U.S. CPI.

b. Figure plots the natural $\log$ of an index that is constructed so that $1990=1$.

period Japan experienced both a higher per capita growth rate than the United States and a real currency appreciation. Accordingly, these postwar subperiods are in the northeast quadrant of figure 3 . This is consistent with the Balassa-Samuelson hypothesis, which, under standard assumptions, predicts that rapid growth will be positively correlated with real appreciation. ${ }^{6}$

However, when all subperiods are examined, the positive relation-

6. For a discussion of the Balassa-Samuelson hypothesis and related references, see Ito and others (1996). 
Figure 3. Japanese Real Exchange Rate Changes and Growth Relative to the United States, Selected Subperiods

Annual real exchange rate change (percent) ${ }^{\mathrm{a}}$

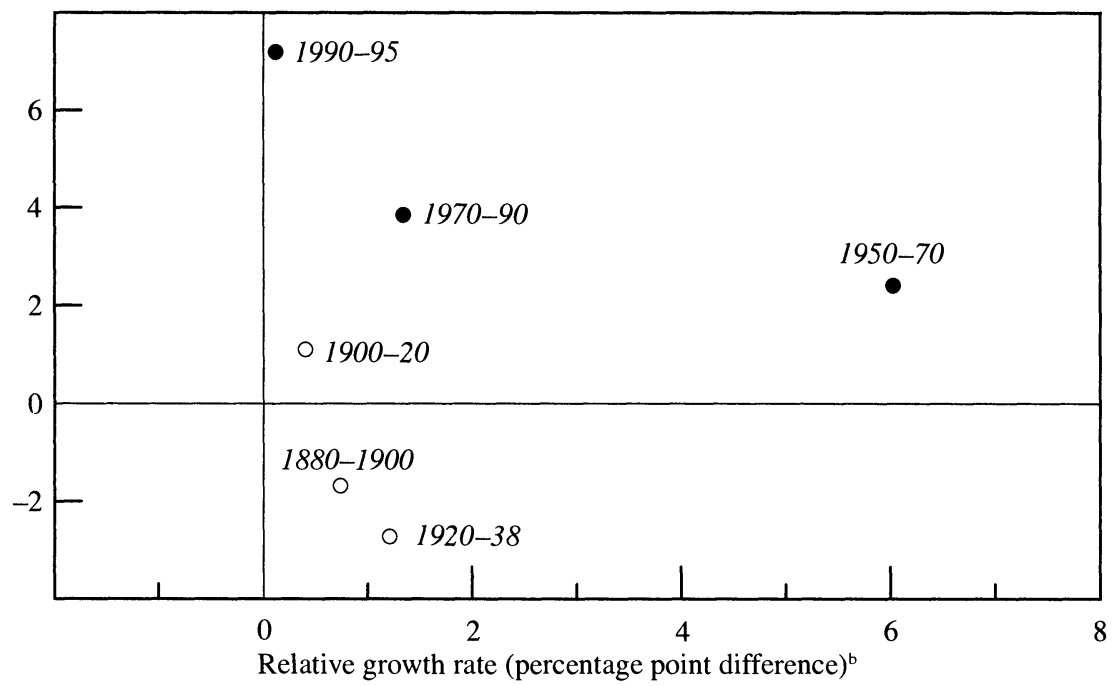

Source: Author's calculations. For sources of GDP data, see table 1; and for exchange rate data, see figure 2.

a. Calculated as $100 \times$ average annual change in the natural log of an index constructed so that $1990=1$.

b. Per capita GDP growth rate: Japan less United States. Prewar data are for per capita GNP.

ship between Japan's relative growth rate and its real exchange rate appreciation disappears. For the prewar period, although Japan's growth rate was higher than that of the United States, the real exchange rate depreciated, on average, in two of the three subperiods. Taking the three prewar subperiods and the three postwar subperiods separately, each shows, if anything, a negative relationship between relative Japanese growth and the real appreciation of the yen. Indeed, in the prewar period, the subperiod with the fastest relative growth (1920-38) also experienced the largest depreciation of the real exchange rate; and in the postwar period, the subperiod with the fastest relative growth (1950-70) had the least appreciation.

Rapid structural change in industry may provide a clue to understanding this relationship between growth and exchange rate behavior. The prewar Japanese economy was heavily dominated by the agricultural sector. In 1885 the agricultural sector (including forestry and fishing) accounted for about 40 percent of net domestic product, while the 
Table 2. Productivity Growth and Inflation, by Sector, Japan and the United States, 1960-92a

Annual percentage rate

\begin{tabular}{|c|c|c|c|c|}
\hline \multirow[b]{2}{*}{ Sector } & \multicolumn{2}{|c|}{ Japan } & \multicolumn{2}{|c|}{ United States } \\
\hline & $\begin{array}{l}\text { Productivity } \\
\text { growth }\end{array}$ & Inflation & $\begin{array}{l}\text { Productivity } \\
\text { growth }\end{array}$ & Inflation \\
\hline \multicolumn{5}{|l|}{ Tradable } \\
\hline Total & 6.86 & 2.96 & 2.85 & 3.23 \\
\hline Agriculture & 3.55 & 4.89 & 3.15 & 4.21 \\
\hline Manufacturing & 6.52 & 1.87 & 2.75 & 3.12 \\
\hline \multicolumn{5}{|l|}{ Nontradable } \\
\hline Total & 3.79 & 5.20 & 0.65 & 5.03 \\
\hline Energy and transportation & 4.36 & 3.98 & 2.64 & 3.78 \\
\hline Construction & 2.77 & 6.89 & -1.53 & 6.94 \\
\hline Distribution and finance & 5.49 & 3.69 & 0.80 & 4.76 \\
\hline Services & 1.87 & 7.70 & 0.50 & 5.64 \\
\hline Difference (tradable less nontradable) & 3.07 & -2.24 & 2.20 & -1.80 \\
\hline Whole economy & 5.29 & 4.27 & 1.32 & 4.50 \\
\hline
\end{tabular}

Source: Author's calculations based on Organisation for Economic Co-operation and Development, National Accounts, vol. 2, Detailed Tables (various years).

a. Productivity growth in a given sector is the annual percentage change in the ratio of total production to total employment for that sector. Inflation in a given sector is the annual percentage change in the CPI for that sector.

manufacturing and mining sector explained only 7 percent. It was not until 1931 that the manufacturing and mining output exceeded that of the agricultural sector. During the gold standard era (1897 to 1917), and also in the 1920s, when policy was directed to getting back on the gold standard, the currency was overvalued and growth was constrained. Appreciation during this period was not the result of productivity gains in the tradable sector, but of deflationary policy mandated by the gold standard. Japan finally abandoned its efforts to maintain the gold standard in 1931, and its currency depreciated sharply, relative to that of the United States, the remaining major gold standard country. The growth in the 1930s was helped by this depreciation and the associated boom in exports.

Between 1955 and 1970, manufacturing's share of GDP increased from 28 percent to 36 percent. However, by 1995, the share of manufacturing had declined to less than 25 percent. Table 2 examines the postwar period in greater detail, showing the changes in labor produc- 
tivity and prices for major sectors of the Japanese economy from 1960 to 1992, and comparing them with their U.S. counterparts.

This breakdown sheds light on the long-run process of Japanese economic growth and puts the yen exchange rate movement in perspective. First, the primary source of Japan's rapid growth was clearly the high rate of productivity growth in the manufacturing sector and the shift of resources to that sector. Furthermore, the productivity growth rate of the tradable sector was higher than that of either the manufacturing or the agricultural sector. This is because of a substantial relative shift of resources to manufacturing, where the level of productivity has always been higher than in other sectors. Second, comparing each sector's increase in productivity and prices, the expected negative correlation between productivity growth and inflation is evident. Third, when Japan and the United States are compared, the productivity growth differentials in tradables, or manufacturing alone, are large. The corresponding differences in price changes are much smaller, and are small relative to movements in the nominal exchange rate. The difference in nontradables productivity growth is also substantial and, again, the relative price movements are much smaller. However, the relative magnitudes of the changes in productivity growth and prices support the notion that the real exchange rate changes are, at least in part, driven by the productivity differentials.

\section{The Bubble and Its Collapse}

Asset prices, most notably stock and land prices, rose sharply in the second half of the 1980s and then declined sharply in the first half of the 1990s. These two periods represent, respectively, the bubble and its collapse. As of the summer of 1996, asset prices are at about their levels before the onset of the bubble. However, their roller coaster ride has left a long-lasting scar on the Japanese economy, in particular on the balance sheets of many financial institutions and nonfinancial corporations.

This section reviews the debate about what really happened and why, the consequences of the bubble, how the bubble could have been prevented, and the challenge to recovery in the 1990s. 
Figure 4. Land and Stock Prices, Japan, 1971-95a

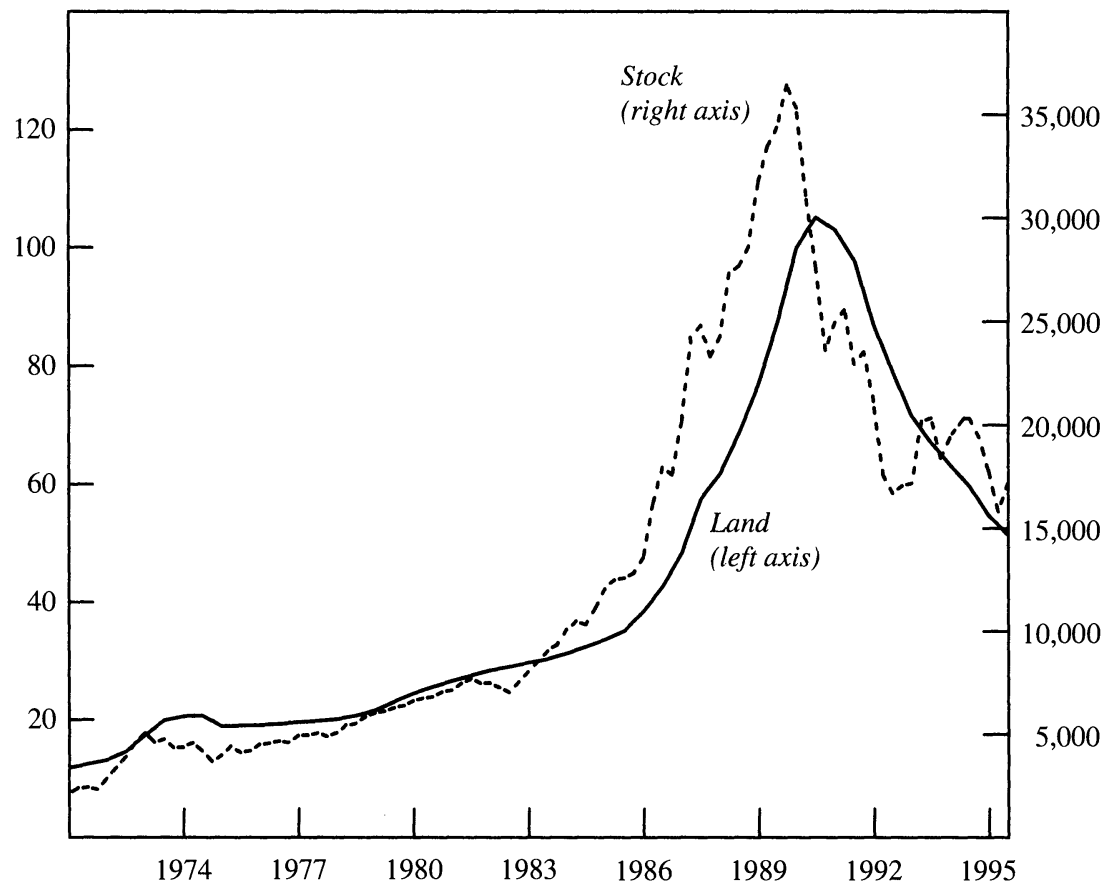

Source: The land price index is the Japan Real Estate Institute's index of prices of all zoning classifications of land in Japan's six largest cities. It is measured at the end of the first and third quarters. Second and fourth quarter observations are interpolated. For stock prices, the author calculates averages of daily closing levels of the Nikkei 225 stock price index, taken from Toyo Kezai Shinposha (various issues).

a. Tic marks correspond to first quarter of given years.

\section{What Happened?}

Movements in stock and land prices are shown in figure 4. Stock prices started their sharp rise in 1983 and increased until 1990. Annual growth rates of stock prices (measured December to December) exceeded 20 percent in all but one year between 1983 and 1989. In 1986, the return reached 44 percent. Residential land prices suddenly started to increase rapidly in 1986 , increasing by 22 percent in that year and 69 percent in 1987. Typically, housing costs almost doubled in two years. Commercial land prices in Tokyo had begun to rise earlier. Land 
prices in Osaka and other major cities followed those in Tokyo with a lag of one to two years.

Stock prices started to decline in January 1990. In the summer of 1992, the Nikkei 225 index fell to around 15,000, a loss of more than 60 percent from its peak at the end of 1989. Although it had recovered to 20,000 by the end of 1992 , monthly averages of the Nikkei 225 have since remained below 22,000, again dipping to 15,000 during the summer of 1995. In 1996, stock prices are at roughly their level of ten years ago. Land prices peaked around the end of 1990, one year after stock prices, and then started on a decline that, although not as steep as that of stock prices, was more sustained. As of 1996, land prices are also at roughly their level of ten years ago.

It is now agreed that most of the increase in stock and land prices during the second half of the 1980 s represented a speculative bubbleprice increases were based purely on the anticipation of future price increases. Disagreement remains as to how much of the price increase was speculative. One of the most telling fundamentals behind asset prices is the cash flow from the asset, given by rents for land and dividends for stocks. Kazuo Ueda notes that dividends did not increase when stock prices rose in the second half of the 1980s, and so the priceto-dividend ratio was higher in the 1980s than it had been in the 1960 s and 1970s. In regard to land prices, Keiko Nosse Hirono and I use a hedonic regression to calculate rents and purchase prices for a standardized high-rise condominium in Tokyo. ${ }^{7}$ We show that during the period of the bubble, the already low rental yield declined to only about 0.25 percent. Real estate investment made sense only with low-cost financing and expected capital gains. There were such capital gains until the end of the 1980s. ${ }^{8}$ However, by the late 1980s, the low and declining direct yield should have been a warning.

\section{Why the Bubble?}

Today, it has become popular to blame Japanese monetary policy in the second half of the 1980s for creating the bubble, although, during the bubble, it was difficult to see why the boom had to stop, considering

7. Ueda (1990); Ito and Hirono (1993).

8. See Ito (1993) for a model of land supply constraints resulting in ever-increasing land prices. 
that general price inflation remained relatively low. Interest rates were lowered from 1985 to 1987 , and then maintained at a low rate until 1989. A relatively small movement in the interest rate can certainly cause a large movement in an asset price. Advocates of this view argue that an asset price can be derived as a present value of future earning stream. Assuming a constant growth in earning and a constant discount factor, the asset price $(P)$ is given by $P_{t}=D_{t} /(r-g)$, where $D$ is the dividend (or rent), $r$ is the discount rate (interest rate), and $g$ is the growth rate of the dividend. The price will increase if the interest rate is lowered, or if the expected value of $g$ increases. If $r$ changes from 6 percent to 4 percent while $g$ remains at 3 percent, the value of $1 /(r-g)$ will triple. Between 1985 and 1987 the official discount rate was, in fact, lowered from 5.0 percent to 2.5 percent. The 2.5 percent discount rate, which was a record low at the time, was maintained until the spring of 1989. Even taking into account that inflation was lower in 1987 than in 1985, there was a substantial decrease in the real interest rate. However, an interest rate change should not be viewed as a onceand-for-all event. If the interest rate change is expected to last only for the duration of a business cycle, the asset price should be less affected. ${ }^{9}$

Additional insight into monetary policy can be gained by examining the monetary aggregate for the second half of the 1980s. Since 1978, the Bank of Japan has announced quarterly forecasts of monetary growth (M2 plus certificates of deposit). The forecast was quite accurate until 1987, in that the ex post monetary growth rate fell within 1 percentage point of the forecast rate. ${ }^{10}$ Between 1987 and 1990 there were several occasions on which actual monetary growth exceeded the forecast growth range, implying, in a stable relation, that there was an unexpected demand shock and an accommodation by the central bank during this period. However, during this period deposit interest rates were being deregulated, making the relation less stable and the forecast less certain.

Finally, the pattern of bank lending to the real estate sector also helps

9. Ito and Iwaisako (1996) show that even if a 2.5 percentage point decrease in the interest rate was expected to last for ten years and subsequently return to its original level, the corresponding increase in the asset price would be limited to a modest 20 percent, rather than the 200 percent increase obtained under the assumption of permanent change.

10. See Ito (1992, ch. 5) for a more detailed description of these data. 
to explain the nature of the boom. Tokuo Iwaisako and I perform regressions explaining changes in land prices and find that growth in loans to the real estate sector is a significant predictor. ${ }^{11}$ Bank lending to real estate increased sharply in the second half of the 1980s. When the bubble burst, many firms had to absorb financial losses and banks accumulated nonperforming loans.

These are the main indicators cited, after the fact, as evidence that lax monetary policy contributed to the boom and bust. Against this criticism, it can be argued that the general inflation level was low, and so monetary policy was on course. The CPI showed no sign of inflation until 1989, and, as measured by the wholesale price index (WPI), inflation was actually negative from 1986 to 1988. In addition, preventing the appreciation of the yen was another motive behind the easy monetary policy. After the yen appreciated sharply from around 260 in February 1985 to 150 in August 1986 (expressed as yen per dollar), monetary policy was directed toward preventing any further appreciation. ${ }^{12}$

In 1989-90 concern about excessive land prices, mainly in response to protests from prospective first-time homebuyers, brought about a turn in monetary policy. The interest rate was raised five times between May 1989 and August 30, 1990. A ceiling on bank lending to the real estate sector was introduced as an administrative guidance in March 1990. A special national tax on large landholdings was introduced, and the assessment of the real estate tax (a local tax) was revised, effectively raising it. These measures finally stopped the increase in asset prices and, in so doing, triggered the bursting of the bubble.

\section{Consequences of the Bubble}

Once the tide had turned, the asset deflation was as swift as the asset inflation had been. By 1992, the Japanese economy was in a recession. Signs of trouble first appeared in the real estate sector and then quickly spread to financial institutions. Many real estate companies and other companies that speculated with excess funds in the stock and land markets found themselves in serious financial difficulties. Construction

11. Ito and Iwaisako (1996, p. 185).

12. See Ito (1992, ch. 11) for some evidence that a soft "target zone" was implemented at that time. 
and real estate companies, large and small, started to default on interest payments to banks. As a result of the burst bubble, therefore, Japanese banks were saddled with a large number of nonperforming loans. ${ }^{13}$ These problems led to reforms in an overall bank policy in 1995, including the introduction of a deposit insurance system and procedures for warning and for liquidating weak and insolvent banks.

From 1992 to 1995, the economy's growth rate remained below 1 percent. Hints of recovery were seen in 1993, but hopes were quickly dashed by the yen appreciation in that year. It is now the conventional wisdom about the period 1993-95 that output and investment in plant and equipment remained weak as a result of the appreciation of the yen, and that consumption and investment were constrained by the negative wealth effect resulting from the burst bubble. Although the burst bubble is not the sole reason for such a slow recovery, it is a major problem.

\section{Could the Bubble Have Been Prevented?}

One lesson for Japan, and also for other economies, from the period of the bubble is that when financial innovation is taking place, a different kind of monetary policy is called for. Several observations arise from recent experiences. Affordable housing cannot be an objective of monetary policy. The housing problem that finally turned monetary policy around in 1989 should have been dealt with by more structural policy. In order to control risk to the banking system, it is desirable to diversify bank portfolios. If particular sectors of the economy are receiving an increasing share of bank loans, the monetary authorities should be concerned. Therefore, in the context of the bubble, an earlier tightening could have been justified as prudent, even if it was not needed to fight inflation. Admittedly, the timing was unfortunate, because deregulation and other changes in the financial system were evolving rapidly. The old regulatory environment, based on interest controls and lending quantity controls, was dismantled before the new supervisory system, more appropriate to the deregulated environment, was fully

13. The banks have been writing off nonperforming loans and passing some of them on to the cooperative credit purchasing companies. For the fiscal year ending March 1996, many banks have reported net losses due to write-offs to housing loans companies (jusen). The Japanese Ministry of Finance reports that at the end of March 1996, the banking sector was holding 35 trillion yen of nonperforming loans, which represents about 7 percent of GDP. 
implemented. Establishing policy on the close monitoring of bank balance sheets, or making sure that banks have that capacity themselves, becomes important in the deregulated environment. Prudential policy would impose a general standard, such as the Basle Accord's risk-based capital standard, and reinforce the deposit insurance system.

In the case of Japan, these efforts did not come in time. For example, the capital standard and the evaluation of potential risk from asset price movements have become more important in the deregulated environment. And the supervision of banks is especially important in an economy where these institutions play a large role relative to direct financing through equities and bond markets. In this regard, the strength of banks and the long-term relationship between banks and corporations are often praised in the literature on the Japanese economy; but the importance of bank supervision is rarely mentioned.

\section{The Challenge for the 1990s}

In the four years from 1992 to 1995, Japan's growth rate was below 1 percent, the lowest rate among the G10 countries. Although the trough of the recession is officially identified as October 1993, the recovery has been extremely weak. The unemployment rate has risen above 3 percent and continues to rise after two and half years of recovery. ${ }^{14}$ Three issues, in particular, are interesting at this juncture for the Japanese economy. First, why is the recession so prolonged and the recovery so weak? Second, does the economy need structural change, and are features of the Japanese system that were once considered its strengths now preventing needed change? Third, what are the changes that would restore growth to the econorny?

The nonperforming loans that weakened bank balance sheets after the bubble burst may have contributed to the weak expansion by limiting the ability and willingness of banks to make new loans. But that effect is hard to document. ${ }^{15}$ The role of the exchange rate is more evident. The yen appreciated by about 15 percent in the first half of 1993 and by another 15 percent in the first half of 1995 (although the second

14. Although the unemployment rate is a lagged indicator of the business cycle, it is unusual that it should be rising so long after a trough. In the previous recession, 1985-86, the unemployment rate rose for six months after the trough in November 1986 and then started to decline.

15. However, see Gibson (1996) for some evidence. 
episode was followed by an offsetting depreciation in the following months). The economic recovery underway at the beginning of 1993 was negatively affected by that year's appreciation, which helps to explain the slow growth in 1993 and 1994. Likewise, the dramatic swing in the yen during 1995, when it appreciated from about 100 in January to 80 in April and fell back to 100 by September, dashed hopes for a strong recovery in that year.

Although at around 110, as of the summer of 1996, the yen is considered to favor Japanese exports, many manufacturing firms are investing abroad in countries where goods can be produced even more economically. The Asian and North American subsidiaries of the Japanese firms, especially in the autombile and electronics industries, have been expanding rapidly in terms of both employment and sales. From 1990 to 1994, the number of employees in the Asian subsidiaries increased from about 500,000 to 1 million; while in the North American subsidiaries, the number increased from 370,000 to 523,000 during the same period. The sales of these subsidiaries have not changed in yen denomination over the period, which implies that sales have expanded by 20 to 30 percent in the currencies of their host countries. As key manufacturing firms expand their overseas operations, they cut back production in Japan. Japanese manufacturing employment fell from 15.7 million employees in 1992 to 14.6 million in 1995 .

The next section examines the conventional wisdom on the Japanese system in light of new, revisionist views, and the following section discusses the final quesion raised above, of how to restore growth.

\section{The Japanese System}

As shown above, Japan's record of growth, especially from 1950 to 1990 , was certainly respectable for an economy without major resources. This section examines several features of the Japanese economy that are frequently cited as contributory factors to this rapid growth. At first glance, many of the institutional features -in both the private sector and the public sector-seem barely to resemble their counterparts in the United States and European countries. However, close examination reveals that similar economic incentives have been at work under different institutional arrangements. 


\section{Positive Views}

Although opinions differ on whether such unique features are essential or superficial to economic growth, the current majority view on key aspects of the Japanese system (at least in the 1950s and 1960s) is described here. ${ }^{16}$

LIFETIME EMPLOYMENT. The conventional wisdom highlights the long-term relationship between Japanese firms and their workers: regular workers are guaranteed a job for life, and the firm does not lay off workers. As a result, involuntary job changes are rare and the unemployment rate is low. ${ }^{17}$ Such an arrangement could be seen as evidence of labor market rigidity that invites inefficiency. However, it is argued that life-time employment is only one element of Japanese labor relations and that, considered as a whole, the system promotes efficiency. ${ }^{18}$

Although continued employment is to some degree guaranteed, job assignment, working hours, and rates of pay are quite flexible. Given that workers are unlikely to quit, a firm can afford to spend the resources needed to select new recruits carefully and then provide often costly on-the-job training. Rotation through different job skills is common in both white-collar and blue-collar employment, especially at the beginning of an employee's career. Rotation makes workers versatile at their present level and prepares them for higher positions in the same organization. This investment in firm-specific human capital helps to increase worker productivity in the long run.

It is often said that productivity increases were mainly due to a combination of innovations in the manufacturing process and better communication between all levels in the firm, from planning and design to production to marketing. This was made possible by a team of ver-

16. See Ito (1992) for greater detail.

17. It is striking that Japan has maintained a low unemployment rate for the past thirty-five years. It was between 1 and 2 percent in the 1950s and 1960s and has been between 2 and 3 percent since the mid-1970s.

18. In fact, only "core workers" receive an implicit assurance of lifetime employment; that is, until age fifty-five (or closer to sixty, lately). Traditionally, women, parttimers, and seasonal laborers have not been covered under this arrangement, and their employment has introduced a certain amount of flexibility into the system. Lifetime employment and a steep age-earning profile started in the late 1920s and 1930s, when some booming industries found that frequent job changes by their employees were detrimental to factory operations. It did not spread to the majority of industries until the end of World War II. 
satile workers who went through on-the-job training together in the same firm. In addition, competition in the domestic labor market and deferred payment (a steep age-earning profile and substantial severance pay that is dependent on the length of service and the most recent salary of the employee) deters workers from shirking on the job or quitting altogether. Thus life-time employment is supported by an equilibrium of implicit contracts, rather than an exogenous constraint. Moreover, it is self-sustaining: life-time employment contributes to the higher growth of a firm, and higher growth makes it possible to maintain lifetime employment.

In short, life-time employment does not guarantee a job specification for life. A Japanese worker may be asked to take up a different job or to transfer to a subsidiary or a related company, according to the needs of production. Such high mobility within the company (or group of companies) has in part been made possible by the presence of labor unions that encompass different job skills within the company. ${ }^{19}$ This system works especially well in an expansionary environment, since the relatively large pool of "underpaid" younger workers makes possible more "deferred" payments to retiring workers. When the organizational hierarchy of a corporation grows, more management positions are created, and therefore deferred payments increase. Although life-time employment is an integral part of Japanese labor relations that makes it possible for firms to enhance their human capital through onthe-job training, it can also be seen as a type of pay-as-you-go company pension system.

THE MAIN BANK SYSTEM. Strong, long-term relationships between banks and firms are aften cited as another source of strength in the Japanese economy. In the 1950s and 1960s, Japanese financial markets were dominated by banks. The stock and corporate bond markets were severely restrained by laws and regulations. ${ }^{20}$ Banks intermediated

19. The economic power of labor unions in Japan has never been great and, in fact, has been declining. Power resides at the local (company) level, as in the United States. While in some European countries the central bargaining process determines wages and work rules not only for the unions that are involved in the negotiations but also for workers in other firms and sectors, this is not the case in either Japan or the United States. The rigidity represented by such union strength is often blamed for the high unemployment rates in Europe, since firms are unwilling to expand their work forces for fear of being saddled with too many workers later.

20. For restrictions on corporate bond issues in the past, see Horiuchi (1996). 
household saving and provided long-term as well as short-term funds. Deposit interest rates were regulated until the late 1980s, and lending rates were implicitly kept low. The Bank of Japan also restrained credit expansion by reviewing the projected lending increases of the major banks each quarter. During the economic boom of the 1950s and 1960s, credit rationing was common. In the traditional macroeconomic view, financial markets that are repressed in this way may not allocate resources correctly.

However, the Japanese banks have played a much broader role than that of lenders with monopoly power. In many cases, a bank not only provides loans to a firm, but also holds its stock. Typically, a firm develops a relationship with a particular bank and relies on its steady support in funding over the long term. In return, the firm uses the bank for major transactions from which the bank earns fees and profits. A bank that has this type of primary relationship with a firm is called a main bank. ${ }^{21}$ The conventional view (as of the end of the 1980s) is that the main bank system has contributed to the efficiency of Japanese financial markets by solving the problem of asymmetric information that is inherent in the separation of ownership and management.

The main bank acts as an agent for investors and lenders to the firm, examining the viability of investment projects and monitoring the performance of management. Individual stockholders do not monitor management efforts, and in Japan institutional investors have not exercised the kind of monitoring power, such as pressing for higher dividends, that they have in the United States. Monitoring by a bank may, in fact, be more effective at overcoming the short-term perspective of market discipline, as exercised through stock prices, threats of hostile takeover, and pressures from institutional investors. Because the main banks take a long-term view, they will allow management to embark on long-term investment projects with fund commitment. Since the main bank holds both equities and debt, it can act without conflict of interests through both loans (secured) and equities (unsecured). Moreover, because the bank is involved in the business, for example by being represented on the board of directors, it can distinguish a temporary cash-flow problem from more serious situations involving fundamental business misjudg-

21. See Aoki and Patrick (1994) for a comprehensive discussion of the main bank system. The system has its origins in the wartime regulation that a firm must designate a bank through which to channel funds to particular industries. 
ment or insolvency. The main bank will be extremely cautious about closing down a failing business by calling in loans; often, it will first send in an extra management team, even including a replacement for the president of the firm, if necessary.

KEIRETSU. In addition to the strong relationship between banks and firms, the Japanese economy is characterized by long-term relationships between businesses in the form of keiretsu, or enterprise groups. There are two kinds of keiretsu: horizontal (across different industries) and vertical (between a manufacturer and its suppliers, or its wholesale distributors, dealers, and retailers).

The most prominent horizontal keiretsu are the "big six": Mitsubishi, Mitsui, Sumitomo, Ikkan (Dai-ichi-Kangyo), Fuyo, and Sanwa. (Some enterprise groups, most notably Mitsubishi, Mitsui, and Sumitomo, originate from prewar, family-owned conglomerates-zaibatsu. When the zaibatsu holding companies were dissolved and monopolistic companies were divided by the Allied force at the end of World War II, the firms in each group remained loosely connected around the main bank.) Each group is composed of between twenty and forty large companies in different industries, from manufacturing to finance..$^{22}$ The objective is to extend and diversify a group's sectoral span. Each group has a strong bank, which acts also as a main bank to group firms. Group firms can hold a limited percentage of stock in each other. Horizontal keiretsu rarely act in an oligopolistic manner: the firms compete with others in the group.

Conventional wisdom on the significance of the keiretsu to the Japanese economy is similar to that on the main banks; they monitor the performance of management. Since group firms hold each other's equities, they are effectively safe from hostile takeovers. Management can therefore concentrate on long-term investment projects, rather than dressing up quarterly earnings reports. On the other hand, if group firms collectively decide that the management in a company has failed, they can replace it quite easily. By encompassing different industries, a

22. The Mitsubishi group is a case in point. The group's core is most often defined by membership in the Mitsubishi "president's club"; by this definition, there were twenty-nine firms as of October 1993. The group includes financial institutions (Mitsubishi Bank, Mitsubishi Trust, Meiji Life, Tokio Marine and Fire), trading companies (Mitsubishi Corporation), shipbuilding and other heavy manufacturing companies (Mitsubishi Heavy Industries), and automobile manufacturers (Mitsubishi Motors), among others. 
horizontal keiretsu aims to maximize economies of scale, or the synergy of the group.

Typically, a vertical keiretsu includes a manufacturer and its various suppliers or the distributors of its products. The beneficial features of vertical keiretsu in the economy have been explained as follows. Trust, reputation for quality, and long-term commitment are all significant elements of the repeated transactions between a manufacturer and its suppliers and distributors. It is very difficult to check the quality of each individual part and product when it is delivered or sold. Moreover, since "lean production" - just-in-time delivery and cutting back on inventory-has become a hallmark of Japanese manufacturing, it is crucial that suppliers make every effort to fill a manufacturer's orders on time. The manufacturer evaluates its suppliers' records of on-time delivery and rewards them with an implicit guarantee of continuing orders. The same principles of quality control, reliability, and commitment are apparent in keiretsu comprising a manufacturer and a network of dedicated distributors.

During the trade conflict between the United States and Japan in the second half of the 1980s, some alleged that keiretsu promote anticompetitive, protectionist behavior. ${ }^{23}$ The sins and virtues of keiretsu have been debated in the literature. ${ }^{24} \mathrm{~A}$ vertical keiretsu is more likely than a horizontal keiretsu to exhibit anticompetitive behavior among it firms. Although the vertical keiretsu is a source of efficiency in production, in some cases, a large manufacturer, seeking to "maintain" retail prices, has refused to deal with deep discount stores.

INDUSTRIAL POLICY. During the 1950s and 1960s, the government targeted certain industries as sunrise industries, providing them with various subsidies and protections against imports and domestic competition to stimulate their expansion and success. They were given policy loans (low-interest loans through government financial institutions, such as the Japan Development Bank and the Japan Export and Import Bank) and foreign exchange allocations. The government also restricted entry to markets that were considered important and crowded. Likewise, some markets were segmented to limit competition.

One influential, although controversial, interpretation of the indus-

23. The keiretsu were a topic of discussion at the Structural Impediments Initiative negotiations held between the two countries from September 1989 to June 1990.

24. See Lawrence (1993) and Saxonhouse (1993) for surveys of the debate. 
trial policy of this period goes as follows. ${ }^{25}$ When a chosen sunrise industry was in its infancy, the government protected the domestic market through quotas and high tariffs, but allowed domestic firms to compete in the captured market. Japanese firms either licensed a technology or reverse engineered foreign products and technology to catch up in technology. As the economy grew and firms accumulated experience in production, the successful ones were able to expand. Increasing returns to scale brought down production costs. And increasing returns to scale were further enhanced when these Japanese firms started to export and became more competitive in the world market. At this stage, restrictions on imports were liberalized. This strategy of import substitution followed by export promotion was most visible in the steel and shipbuilding industries.

In fact, this kind of targeting was almost inevitable in the 1950s, because the yen was overvalued and import restrictions (including quotas, tariffs, and foreign currency allocations) were necessary to maintain the fixed exchange rate system set by the Bretton-Woods regime. The Ministry of International Trade and Industry (MITI) and the Ministry of Finance promoted particular industries simply by allowing them to use foreign currency allocations to buy raw materials.

Opponents of this view point to failures in the government's attempt to identify prospective sunrise industries: coal, petrochemicals, oil refining, and aluminum are examples. In fact, if productivity increases are regressed on loans from the Japanese Development Bank at the industry level, the relationship is negative. ${ }^{26}$ Consumer electronics, probably one of the most successful export industries, never was on MITI's list of sunrise industries. The automobile industry is another interesting case. In the early 1960s, MITI attempted to merge several automobile manufacturers into two groups of firms, arguing that there were too many automobile manufacturers in Japan. The firms fought back and maintained their independence. If MITI had succeeded in reducing their number, domestic competition would have been stifled and Japanese automobiles might not have dominated the world market in the 1980s.

25. See Itoh and others (1988) and Komiya, Okuno, and Suzumura (1984).

26. See Beason and Weinstein (1996). 
A broader consensus has been achieved on the beneficial effects of the government's commitment to export promotion in general. ${ }^{27}$ Export promotion was certainly an important aspect of industrial policy in the 1950 s and 1960 s, but it too was largely a necessary response to the overvalued currency. Unlike an import substitution policy, export promotion is subject to the test of world markets. Success is judged by foreign customers, rather than captive domestic customers.

The composition of Japanese exports has changed quite rapidly during the postwar period, shifting from textiles and toys to other light manufactured goods in the 1950s; to consumer electronics, steel, and ships in the 1960s and 1970s; to sophisticated optical products in the 1970s; and to automobiles and semiconductors in the 1980s. The structural transformation of industry was one source of Japan's continuous success at achieving trade surpluses and rapid economic growth.

SAVING AND INVESTMENT. The Japanese household saving rate has long been the highest among the major OECD countries. As measured in the household survey, it rose from about 15 percent in the mid-1950s to above 20 percent at the beginning of the 1970s, after which it started to decline; it is now again at 15 percent. ${ }^{28}$ The high saving rate makes it possible to realize a high investment rate without borrowing from abroad.

Japan's high saving rate has been the focus of much study. ${ }^{29}$ Opinions differ on whether the saving rate can be understood purely in terms of the life-cycle hypothesis, in which people save for retirement during their productive years. One of the consequences of the hypothesis is that the saving rate rises with the growth rates of population and income. In other words, cross-country differences in demographic structures and income growth rates will predict differences in aggregate saving rates, even if households are identical across countries and periods.

Although the qualitative prediction of the theory seems to fit the Japanese experience, the magnitude is questionable. In particular, some economists have suggested that, in Japan, household saving decisions are dominated by the bequest motive. Some surveys do suggest that

27. See, for example, World Bank (1993).

28. See Ito (1992, pp. 280-82) on the various data sources for the saving rate.

29. See Hayashi (1986), Horioka (1990), and Ito and Kitamura (1994), and their references. 
Japanese households save more than their U.S. counterparts in each age bracket. ${ }^{30}$

EDUCATION. Illiteracy is extremely rare in Japan. Elementary and high school education emphasizes basic skills in language and mathematics, as well as group activities. Curriculums are nationally standardized, and it is not possible to skip a grade. University admission is by examination, with stiff competition. It is widely accepted that the Japanese education system produces highly qualified and effective workers.

MACROECONOMIC AND FINANCIAL POLICY. Despite the popular image of wide-ranging industrial policy and an interventionist government, the national budget has historically been small relative to GDP in Japan. There is a separate public investment program, known as the Fiscal Investment and Loans Program, that is funded from the postal saving system, but this money is generally used for government investment in infrastructure. Therefore, at least in terms of the budget, Japan has maintained a small government, even during its developmental stage. Monetary policy has been successful at accommodating financing needs with limited general inflation, except during 1973-74 and the period of the bubble.

Government revenues and expenditures were, in effect, balanced until 1965. Government bonds for infrastructure (so-called construction bonds) have been issued since 1965, and deficit financing bonds since the mid-1970s. Government deficits grew rapidly in the second half of the 1970s, but fiscal austerity had staunched the issuance of new deficitfinancing bonds by 1990 .

In retrospect, it can be seen that mistakes in monetary policy were committed at times of major regime changes. Monetary policy became too lax in 1972, partly in response to yen appreciation and partly at Prime Minister Tanaka's request, because of his "reconstruction of the Japanese archipelago" initiative. This added to wild inflation of 1973 that had been triggered by the first oil crisis. Monetary policy is also blamed for fueling speculative activity at the height of financial deregulation and innovation in the late 1980 s, thereby contributing to asset price volatility. Both of these episodes were related to the determina-

30. On the dominance of the bequest motive, see Barthold and Ito (1992) and Hayashi, Ando, and Ferris (1988); and for survey data, see Takayama and Kitamura (1994) and Poterba (1994). 
tion of the business community and the government to prevent yen appreciation. ${ }^{31}$

The expansion of government deficits in the second half of the 1970s can be attributed to several factors. First, the government might have mistaken the potential growth rate. ${ }^{32}$ As discussed above, trend growth rates declined sharply in 1973-74, but many economists in the mid1970s believed that Japan would return to higher growth rates (of 8 to 10 percent) once oil prices were stabilized. Accordingly, the government overstimulated the economy with deficit spending. Second, the social security reforms of 1973 proved more costly than anticipated. Third, it was expected that broad-based indirect taxes would fill the fiscal gap, but the proposed legislation never materialized. Fourth, the Bonn Summit of 1978 demanded that Germany and Japan further stimulate their economies in order to reduce their trade surpluses and promote growth in other industrialized countries, notably, the United States. Budget deficits reached 6.0 percent of GNP in 1979.

As a result of a strong economy and speculative activities that produced unexpectedly high tax revenues in the late 1980s, no new deficit bonds were issued in 1991 or 1992 . However, budget deficits have grown since 1993, as the government has attempted to lift the economy out of recession.

\section{Critical Views}

The features that used to be considered strengths of the Japanese economy are now considered by some to be obstacles to overcoming the difficulties of the 1990s. ${ }^{33}$

LIFETIME EMPLOYMENT. Conventionally regarded as an effective way of accumulating firm-specific human capital, the guarantee of lifetime employment might be detrimental to the firm in the 1990s for two reasons. First, in the current climate of slow growth in domestic corporate investment, the promise of lifetime employment cannot be upheld. Second, the type of innovation that would increase growth in

31. Ueda (1993) also considers these two episodes to have been mistakes of monetary policy.

32. See Asako, Ito, and Sakamoto (1991).

33. Some of the following arguments can be found in Japan, Economic Planning Agency (1996). 
Japan in the 1990s cannot take place in the context of labor relations that hinge on lifetime employment.

The principle of using deferred payments to motivate workers is now in danger of self-destruction for the same reasons that a pay-as-you-go pension system runs into difficulties in an aging economy: arrangements that worked in a high-growth environment begin to fail. When future corporate growth estimates are revised downward, the forecasts of the deferred payments that will ultimately be paid to current workers follow. If zero growth continues for about another decade, it is quite likely that workers who are now in their forties will retire to find that their age-earning profiles have not been as steep as those of the previous generation-a subtle breach of implied contract. The recent increase in the unemployment rate foretells the prospect, although firms, concerned to maintain their reputations in the eyes of prospective recruits, have so far honored their implicit contractual obligation not to lay off workers.

In addition, the type of innovation sought in the 1990s seems to be difficult to generate with the Japanese system of labor relations. On the frontier of development are high-technology, service-oriented industries, such as computer software, communications, and financial products. These industries are typically supported by venture capital businesses, and they employ workers with highly specialized skills. In this context, the Japanese way of educating and training workers to be versatile is counterproductive. The limitations of job rotation and employment security have become obvious.

THE MAIN BANK SYSTEM. The role of the main bank system in the 1990s is also open to question. In this case, there are two strands of argument. First, banks generally play a diminishing role as industrial economies mature. Second, the behavior and performance of Japanese banks during the bubble and its collapse have cast doubt on the conventional view.

During the period of the bubble (1985-90), firms were able to issue new equities because stock prices were expected to rise. Domestic corporate bond markets were still regulated, both through restricted access and through underwriting fees, but firms were able to issue Euroconvertible bonds and warrants on favorable terms. ${ }^{34}$ Some firms repaid

34. In fact, these bonds were also purchased by Japanese institutional investors; they 
all their bank loans and freed themselves from the main banks. Since Japanese financial markets have been deregulated, the need for main banks, and banks in general, has clearly declined.

Throughout the 1980s, the industrial countries, including Japan, rapidly liberalized their financial markets. Regulations on interest rates were abolished; entry into new services and geographical regions (domestic and international) was increasingly liberalized; and new products and markets, most notably derivatives, were developed. In Japan, most controls on capital inflows and outflows were lifted in the first half of the 1980s. On the domestic front, all interest rate regulations had effectively been lifted by the beginning of the 1990s. The Bank of Japan's restrictions on lending increases by the major banks were abolished in 1994. As regulations on capital controls, corporate bond issues, and new stock offerings were dismantled, corporations were able to raise funds directly in domestic and international capital markets instead of borrowing from banks. Borrowing costs started to reflect the credit risk of corporations, and corporate information was made open to the market, rather than being hidden in earnings reports that could only be deciphered by the main banks.

However, the most damaging evidence on the role of the main bank system is that when the bubble burst, the number of nonperforming loans soared and bank balance sheets became fragile. The burst bubble affected Japanese banks in two ways, one familiar and the other quite Japanese. First, the sharp decline in land prices hurt both speculators and developers-both those who held land merely on the prospect of rising prices and those who held land with the intention of developing it. As speculators and developers went bankrupt, banks were left with nonperforming loans or repossessed collateral with inflated book value. In many instances, a bank extended loans to real estate-related projects in amounts close to market value, so that when land prices declined, collateral did not cover the outstanding loans. Banks have got into trouble in this way in many countries. For example, similar problems occurred in the 1980s in the United States, with the savings and loans crisis, and in the Scandinavian countries.

Second, the decline in stock prices also hit the banks' balance sheets.

had to go to the European market both to issue and to purchase their corporate bonds in order to avoid the regulations, steep fees, and commissions in Japan. All eligibility restrictions (ratings) on corporate bond issues were eliminated in 1996. 
As noted above, many Japanese banks have substantial holdings of stock in the firms and groups of firms with which they have long-term relationships. On the balance sheet, these long-term holdings are valued at the original purchase price, which is far below market value. This kind of unrealized capital gain (fukumi) serves as a financial buffer for banks faced with unexpected losses (for example, when a loss-making subsidiary is liquidated, or a rogue trader causes huge trading losses). The banks could easily have dealt with the nonperforming loans due to the decline in land prices if stock prices had not declined at the same time. Moreover, some of the unrealized capital gains were eligible to be counted as tier 2 capital in the Basle Accord's risk-based capital standard, which was scheduled for implementation by the end of March 1993. The fall in stock prices in 1990 and 1991 brought the capital ratio of Japanese banks close to the 8 percent minimum. The decline in the value of these unrealized capital gains and its implication for the capital standard was partially alleviated by a new administrative guidance that allowed banks to issue subordinated debt (which is also counted as tier 2 capital) to be purchased by institutional investors. However, this subordinated debt reportedly carries high interest rates. ${ }^{35}$

In the mid-1990s, it has become clear that healthy manufacturing firms can raise funds from capital markets on more favorable terms than banks are willing to offer. On the other hand, the decision of banks to extend such large amounts of debt to the real estate sector shows that they are no more prudent than other corporations in a deregulated world. If the banks are so smart at monitoring the investment projects and management performance of the firms to which they lend, surely they could have monitored themselves to avoid the nonperforming loans.

The nonperforming loans of housing loan companies (jusen) became the focus of attempts to tackle the general problem of nonperforming loans in 1995. The jusen had borrowed from banks and agricultural cooperatives and lent to the real estate sector. Most of these loans became nonperforming when the bubble burst. When the situation was finally resolved, in December 1995, the expected net losses (nonperforming loans less expected recovery values) due to the defaults of the

35. Precise information on the interest rate is not available because there is no secondary market in these debts. 
jusen were estimated at one-third of the total expected losses of the banking sector. ${ }^{36}$

One characteristic of the main bank system is that banks other than the main bank also lend to the firm, relying on the monitoring ability of the main bank. Banks collectively share the task of monitoring firms, while diversifying their risks. Bank lending to jusen in the late 1980s was conducted in a similar manner. Although an individual jusen is a subsidiary of a group of banks, it receives loans not only from its parent banks but also from other banks, as well as from credit cooperatives. The fact that banks were in overall charge of lending and of monitoring management teams composed of former bank employees and former officials of the Ministry of Finance probably encouraged the agricultural cooperatives to rely on their parent banks' assessments of the creditworthiness of jusen business.

In resolving the jusen losses, the greatest burden was laid on the banks that had originally founded the jusen. This might be consistent with the conventional view of the main bank system, in that the main bank is implicitly responsible for the financial troubles of the firm. However, it also indicates (possibly terminal) difficulties in the relationship. Many banks, especially the smaller ones, have lost so much of the cushioning around their core financial soundness as a result of nonperforming loans that further problems would threaten their survival. Moreover, faced with increasing competitive pressure as financial markets become integrated, banks will no longer be able to absorb losses that are not already disclosed on their balance sheets.

KEIRETSU. The strengths of the keiretsu do not seem to be effective for Japanese growth in the 1990s. The current frontier of technological

36. The seven jusen borrowed a total of about 13 trillion yen in 1995, of which 6 trillion yen was from banks and 5.5 trillion yen from agricultural cooperatives and their prefectural federations (ken shin ren), which collect and jointly manage funds from individual cooperatives. Of the 6.4 trillion yen in immediate losses, 5.2 trillion yen was to be shouldered by the banks, while the liability of the agricultural cooperatives was limited to 530 billion yen. The government agreed to inject 680 billion yen from the budget for fiscal year 1996 to fill the gap. However, the government's outlay is expected to be recovered by the long-term profits on a fund set up by the banks. This outcome is widely regarded as evidence of the political clout of the agricultural cooperatives. The delayed resolution of the situation and the relatively large burden imposed on the banks damaged their balance sheets and may have diminished their financial competitiveness. (See also the discussion of Japanese financial services below.) 
innovation is in industries and companies that are not traditionally affiliated with keiretsu. The horizontal keiretsu are typically composed of large companies in finance and manufacturing. It is not these established firms that are likely to experience the next wave of expansion, but service sector industries, such as computer software, transportation, discount retailing, and entertainment.

For their part, the vertical keiretsu are not generally suited to the organizational needs of the service sector. In the manufacturing sector, further efficiency will depend on the initiatives of large discount stores and other retailers to eliminate intermediaries, or at least to reduce transportation costs and the profit margins of wholesalers, not on the keiretsu relationship. Moreover, the relationship between the manufacturers and suppliers is experiencing a different challenge. Due to the strong yen, a growing number of manufacturers is investing abroad. Some small suppliers that have provided these firms with just-in-time deliveries are finding it difficult to follow them to assembly sites abroad.

INDUSTRIAL POLICY. The role of traditional industrial policy and export promotion is unquestionably minimal in Japan in the 1990s, as compared with the past. It is not likely that sustained high growth in the Japanese economy in the future will come from increasing exports. As a result of trade conflicts with the United States in the late 1980s and the early 1990s, the promotion of imports has begun to be emphasized at the expense of exports. MITI has established various initiatives, including providing foreign exporters with rent-free offices in Tokyo.

SAVING AND INVESTMENT. Rapid demographic change is projected to give Japan one of the oldest populations in the world by 2025 . The ratio of productive persons (ages fifteen to sixty-four) to retired persons (ages sixty-five and over) is projected to decline from 5.8 in 1990 to 2.3 in $2025 .{ }^{37}$ Even this estimate may be too optimistic, since in the past few years the birth rate has fallen below that estimated in the 1992 projections. According to the life-cycle hypothesis, the more retired persons there are, the lower the saving rate becomes. A lower saving rate will reduce Japanese current account surpluses (by increasing domestic consumption without changing investment), reduce growth (by lowering investment), or both. In any case, demographic change over the next thirty years will probably bring down the Japanese growth rate, unless 
productivity increases more than offset the lower investment rate. ${ }^{38}$ Even if the bequest motive pushed up the saving rate in the past, it is not certain (or even likely) that the bequest motive remains strong today, since the value of household stocks (durables and financial assets) is now so much greater. It seems inevitable that the Japanese saving rate will decline in coming years.

Japanese investment is decreasing in the 1990s. This is partly in reaction to the high levels of investment during the period of the bubble, but it is also partly a result of the fact that manufacturing firms are investing abroad. If investment abroad is only a temporary phenomenon, then investment in manufacturing will recover soon. However, if the real exchange rate remains high, recovery is unlikely to be imminent.

EDUCATION. The Japanese education system has successfully produced a homogeneous, group-oriented labor force, well versed in basic skills. However, many now argue that the current system does not foster the creativity and specialized skills needed to make breakthroughs in research. In particular, it appears that students are not learning highly specialized computer-oriented skills.

The strong pressure to pass university entrance examinations encourages high school students to study hard without questioning the material, and trains them to memorize facts rather than to think independently. Moreover, since students cannot enter university early (they cannot skip a grade, nor is there any equivalent of the U.S. gifted programs that go beyond the curriculums necessary to gain admission to university), creative thinking and specialized training typically must wait until students are eighteen. And some students are burned out by that time. Finally, the use of computers is limited in elementary and high school education. The ratio of computers to students is typically lower in Japan than in the United States, and it appears that Japanese curriculums lag behind those in the United States in terms of information technology.

MACROECONOMIC FUNDAMENTALS. Government deficits rose sharply in the first half of the 1990s. Once again, this was a response to a weaker than expected economy. At this point, it is not certain that the

38. For a comparative study of Japan and the United States on issues related to an aging population, see Noguchi and Wise (1994). 
potential growth rate has changed markedly in the 1990s. If it has, indeed, slowed down, the deficit financing in the first half of the 1990s was a repeat of the mistakes of the second half of the 1970s. However, reducing the deficit in the future will be more difficult than was fiscal consolidation in the 1980s. The aging population is lowering the ratio of productive to unproductive workers and laying the burden of deficit reduction on workers, either by raising taxes or by curtailing government services, will be a political challenge.

\section{Toward Structural Reform}

As discussed above, the very features for which the Japanese economy has been praised in the past seem now to be set against further growth. Unless there is some structural reform, new industries will not emerge and the slow growth will continue. The appropriate kind of reform and the new leading industries that might emerge are debated intensively in Japan. The differential growth rates of different sectors, which were touched on in regard to the Balassa-Samuelson hypothesis, are suggestive of the problem. Table 3 presents ten-year breakdowns of the data in table 2 to show how productivity growth rates have been slowing down over the past three decades. The effect is seen across the board, but services, construction, and agriculture are at the bottom of the productivity ranking. Moreover, construction and services registered large price increases in the 1980s. The agricultural sector had the fourth highest rate of price increase in the 1970s, but its rate was moderate in the 1980 s.

The apparent negative correlation between the productivity growth and price increase is consistent with theory. The less labor productivity increases, the more labor costs increase. Slower productivity gains in certain sectors are typically regarded in the literature as technologically given. However, it might be that competition in these sectors is not intense enough to force management to pursue maximum efficiency in production. This is especially plausible in the Japanese context, because the sectors with slow productivity growth are nontradable sectors, for which competition from abroad or by foreign companies in Japan has been minimal. In addition, it is possible that legal barriers and regulations have constrained these industries more than others. This argument 


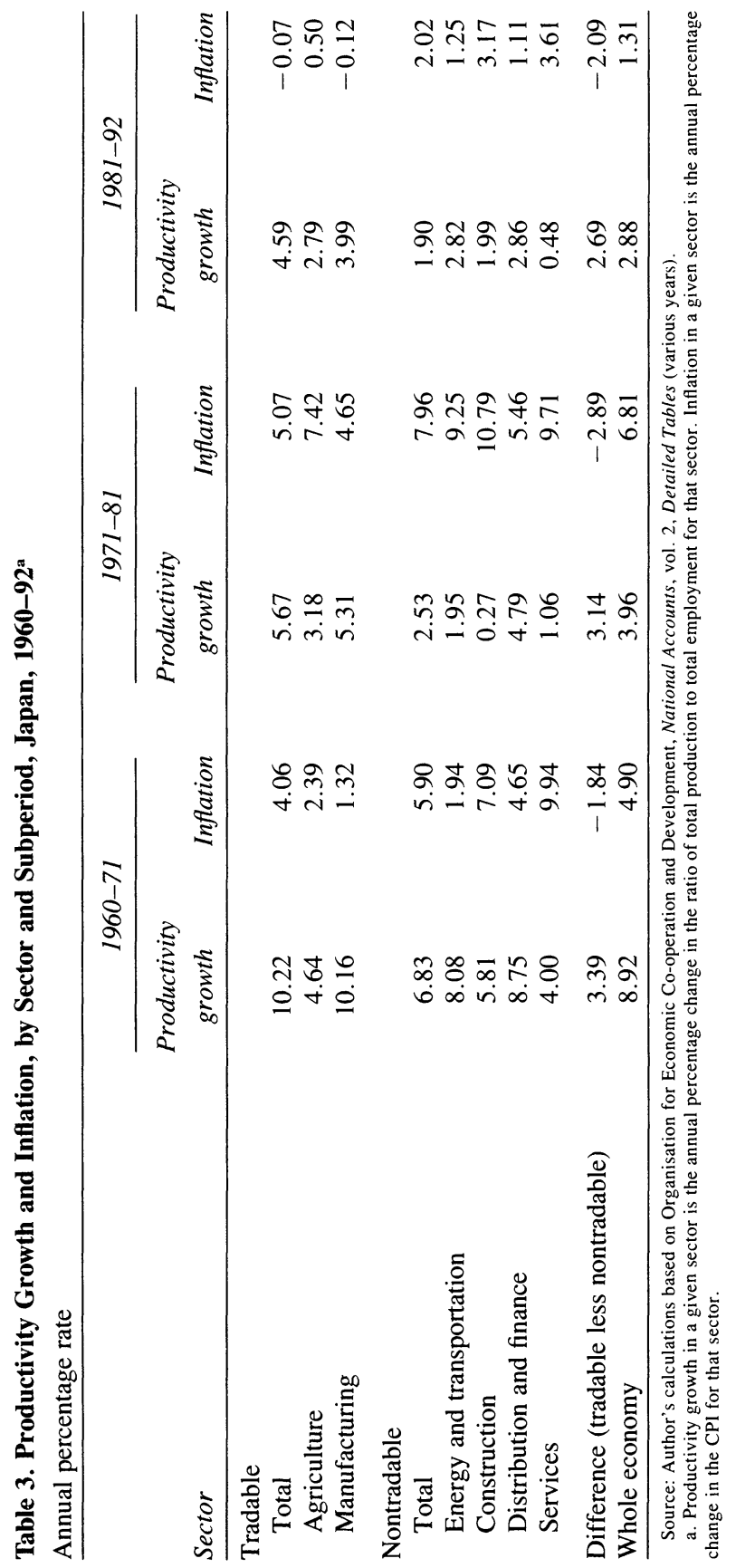


is supported by the observation that the focus of fair trade complaints against Japan by the United States has shifted from particular Japanese manufactured exports to access for U.S. companies to nontradables markets in Japan. For example, such complaints have highlighted the large-scale retail store law, in regard to distribution (for example, the opening of Toys ' $R$ ' Us stores in Japan); trust banks and investment advisory services for pension fund management; and procurement contracts for the construction of the new Kansai airport. The export of U.S. rice and apples to Japan has also been hotly debated. While these are tradable goods by nature, Japan has restricted their import for political and other reasons.

Further evidence that the nontradable sectors are causing higher prices in Japan is given by a direct price comparison, using a fixed consumption basket. According to the Japanese Economic Planning Agency, in November 1994 the cost of living in Tokyo was approximately 50 percent higher than that in New York. Notably, rents and the prices of energy and utilities are about twice as high in Tokyo, while food and clothing prices are close to 70 percent higher. ${ }^{39}$

A welfare implication of the Balassa-Samuelson hypothesis is that real exchange rate appreciation is usually a blessing, because it shows that a country's productivity growth in tradable sectors is higher than that of its trading partner. The implicit underlying assumption here is that nontradable sectors grow at similar rates across countries. However, the Japanese experience in the 1990s-real currency appreciation with only average productivity growth in tradable sectors-indicates another interpretation of the Balassa-Samuelson hypothesis is possible: appreciation may be a sign of slow productivity growth in nontradable sectors, which is hardly a blessing.

Deregulation and measures to enhance competition in the slow growth sectors will be beneficial from the point of view of consumers and also for overall economic efficiency. Discussions follow of several sectors and industries that might benefit from structural reform.

\section{Airlines}

The experiences of Japan's airlines illustrates that regulations stifle an industry and that deregulation substantially lowers the price of ser-

39. Japan, Economic Planning Agency (1995). 
vices. ${ }^{40}$ Air routes and airfares in Japan were heavily regulated until 1986. New entry into the market was prohibited and airfares were proportional to the distance of the routes, regardless of demand and supply. Under administrative guidance, the three major airlines divided up the markets: Japan Air Lines took all major domestic (trunk) lines, as well as regular international service; All Nippon Airways took domestic lines and also short-range international charter services; and Toa Domestic Airlines (subsequently, Japan Air System) took short-range domestic service. Many domestic routes were served by only one airline, a few by all three.

In 1986 the process of reform was started by allowing new entry to specific routes. For example, Japan Air Lines took more domestic routes and All Nippon Airways took a few regular international routes. However, in general, airfares were still tightly regulated; only the multiple-coupon discount gave a fixed rate off the official fares. As a result, airfares for a given distance were much higher than in the United States. Hirotaka Yamauchi and I compare domestic airfares in Japan and the United States for the late 1980s and early 1990s and find that, in most cases, the unit price (yen per kilometer) of discounted fares in Japan was twice (on short routes) or three times (on long routes) as high as in the United States. ${ }^{41}$ One major problem was the Ministry of Transport's restrictive guidelines on setting airfares and ceilings on discounts.

The regulation of airfares in Japan was substantially relaxed only in 1996. Although regular fares are still based on distance, airlines now have greater flexibility in setting these fares, and the ceiling on discounts has been raised to 50 percent of the regular fare. The airlines immediately introduced various discount fares, based on season, time of day, advance purchase, and restrictions on changes and refunds: all features that appeared in the U.S. market fifteen years ago, in the wake of airline deregulation. However, because air routes and the frequency of service are still regulated, it remains virtually impossible to develop an innovative route system, such as the hub-and-spoke system pioneered in the deregulated U.S. market of the mid-1980s.

It is not clear that regulation has helped the Japanese airline industry.

40. For detailed discussion, see Yamauchi and Ito (1996).

41. See Yamauchi and Ito (1996). 
Although the three carriers were highly profitable during the period of the bubble, both Japan Airlines and Japan Air System reported sustained losses in the first half of the 1990s. Moreover, even in international markets, such as between Japan and North America (including Hawaii), Japanese carriers are losing ground to their foreign rivals. The ratio of passengers on Japanese carriers to the total passengers over the Pacific declined from 40 percent in 1986 to 33 percent in 1994.

These competitive losses on international routes and the high domestic prices (or lack of discounts) show that regulations have prohibited innovative management and stifled productivity growth in the airline industry. During the bubble, these problems were hidden by buoyant demand; when the bubble burst, it became all too clear that change is long overdue. ${ }^{42}$

\section{Telecommunications and Broadcasting}

Until 1985, the provision of telephone services in Japan was divided into international and domestic markets, monopolized by Kokusai Denshin Denwa (KDD) and Nippon Telephone and Telegraph (NTT), respectively. In that year, deregulation allowed one set of new entrants into the international market, and another into the domestic long-distance market. Local service remained a monopoly of NTT. ${ }^{43}$

International charges have declined by half over the past decade. Likewise, NTT halved its domestic long-distance telephone charges (measured by the maximum distance) between 1985 and 1992, mainly due to pressure from new entrants to the market. The details of access to local markets (for example, the degree of openness and how to set access charges) have not yet been completely resolved, and NTT maintains its advantageous position relative to other long-distance companies. These data show that deregulation and competition are powerful forces for lowering the price of services.

Several major problems remain, however. First, domestic long-distance and international services are still separate, so scale economies cannot be fully implemented. Second, debate continues as to whether

42. After the first draft of this paper was written, the Japanese Ministry of Transport announced that it will allow new companies to enter the domestic market. Two companies plan to enter the Tokyo-Sapporo route over the next two years.

43. The extent of deregulation and its effects on other industries are discussed in detail by Okuno, Suzumura, and Nanbu (1993). 
NTT should be divided regionally, or a long-distance division of the company should be separated from the local monopoly, or there should be some other arrangement that would combine the two options.

Third, local charges in Japan are proportional to the length of the call (typically 10 yen for three minutes). Although this system has not been a problem for regular voice use, it becomes an issue with the widespread use of the internet and the worldwide web. In the United States, arrangements for unlimited local calls at a fixed monthly fee (typically, around $\$ 25$ a month) are prevalent. Despite recent initiatives allowing unlimited local calls late at night, the situation in Japan is much different. ${ }^{44}$ Some argue that proportional charges are responsible for the slow spead of telecommunications in Japan. It is estimated that, as of January 1, 1994, there were more than 10 million internet users in the United States, while in Japan there were approximately 330,000, less than half the number in Germany, the United Kingdom, or Australia.$^{45}$ Here is evidence that high nontradables prices are preventing the growth of the new information industries in Japan.

Broadcasting is another service industry that provides a stark contrast between Japan and the United States. In the United States, cable television systems spread rapidly throughout the 1980s, and by the early 1990s, many urban households had access to forty to fifty channels through a community antenna television (CATV, or "cable television") system. ${ }^{46}$ In Japan, few households subscribe to CATV service. Satellite television-direct reception by individual households, via a dishis popular: more than 6 million households subscribe to the satellite channels of the public broadcasting corporation, Nihon Hoso Kyokai. But only four channels are available from broadcasting satellites. A greater number of channels are available from communications satel-

44. Since August 1995, NTT has offered customers unlimited calls to only two registered local numbers between 11 p.m. and 8 a.m., for the monthly fee of 1,800 yen. Other carriers offer various discounts on monthly fees, some without restrictions on the timing of calls. Nevertheless, the costs of using the internet are extremely high in Japan relative to the United States.

45. Joho Tsushin Sogo Kenkyujo (1994).

46. In the United States, the incidence of cable access among households with televisions grew from less than 50 percent in 1980 to close to 90 percent in 1990, while in Japan the incidence was around 10 percent in 1995. An estimated 3 million households subscribe to CATV service, out of a total of more than 40 million households in Japan. (U.S. numbers are from Levy and Setzer, 1991; Japanese numbers are from the Japanese financial press.) 
lites, although at a much higher cost. In October 1996 digital broadcast satellite television ("perfect television") service was initiated, providing more than sixty channels; it remains to be seen how popular it will become.

These new developments in telephone and CATV are important. The services provided by the telecommunications and the broadcasting industries will increasingly overlap in coming years. It is technologically feasible to carry local telephone service over CATV systems, and provision is likely to be realized soon. Teleconferencing on the internet (in effect, a local telephone call for the customer) could replace longdistance and international telephone calls. And banking and financial services (settlements as well as transfers between accounts) could also be offered through the internet. Given these imminent innovations, the current state of telephone service, internet access, CATV systems, and other broadcasting services in Japan suggest that rapid and major change is needed to catch up with the United States.

\section{Financial Services}

Hollowing out, which occurs when domestic firms move their operations abroad and is a sign of loss of competitiveness, is not limited to the manufacturing sector in Japan: some analysts claim that it is also evident in the financial sector. This argument is based on at least two sets of developments. First, when the same or similar products can be issued or traded either in Japan or abroad, Japanese businesses tend to go abroad, due to high domestic fees on issuance and transactions. For example, Nikkei 225 futures are traded on the Osaka Securities Exchange (OSE), the Singapore International Monetary Exchange (SIMEX), and the Chicago Mercantile Exchange (CME); Euro yen interest rate futures are traded on both the Tokyo International Financial Futures Exchange (TIFFE) and SIMEX; corporate bonds are issued in Japan and in the Euro market; and Japanese stocks are traded both in Japan and on London's Stock Exchange Automated Quotations (SEAQ) international. ${ }^{47}$ Second, the number of firms listed on the Tokyo Stock

47. The most frequently quoted statistic is that SEAQ transactions have grown to 30 percent of transactions of the same stocks on the Tokyo Stock Exchange (TSE). However, this may be an exaggeration: SEAQ transactions will be double-counted if SEAQ members trade stock among one another, and a transaction by a SEAQ member is 
Exchange (TSE) has been declining since 1991, and firms expanding out of emerging markets in Asia tend to choose the New York Stock Exchange (NYSE), rather than the TSE, for their first listing abroad. ${ }^{48}$

I elaborate only on the first issue here, focusing on competition between the OSE and SIMEX ${ }^{49}$ As discussed above, Japanese stock prices rose sharply from 1985 to 1989 and then plummeted between 1990 and 1992. Nikkei 225 futures trading was first introduced on SIMEX in 1986, and then on the OSE in 1988, and on the CME in 1990. Aided by the increasing stock prices and heavy domestic trading, the market share of the OSE in global Nikkei futures trading exceeded 95 percent in 1991. However, from 1992 to 1994 the market share of SIMEX increased at the expense of the OSE. The value of transactions on SIMEX had grown to about half of the value of transactions on the OSE by the end of 1994. Many consider that the OSE lost trades to SIMEX, in part, because of the high cost of transactions on the OSE, including transactions tax, commissions, and margin requirements. For example, between 1990 and 1991, the OSE raised its margin requirement from 15 percent to 30 percent (in three increments), while SIMEX lowered its margin requirement from 12 percent to 8.8 percent. The OSE's 30 percent margin requirement was maintained through the next two years; the SIMEX margin requirement was raised to 14.2 percent in 1992, but had been cut back to 8.5 percent by August 1993 .

Each change in margin requirements in SIMEX was preceded by a change in return volatility in the same direction (lower volatility preceded a lower margin requirement, and vice versa), whereas the in-

counted even if it is transacted abroad. There is little evidence that Tokyo-based investors have shifted transactions to London from Tokyo because of costs. The increase in SEAQ transactions may be understood in terms of increased European interest in Japanese stocks and the convenience of making transactions in local time. Indeed, the increase of foreign investors relative to Japanese investors is apparent from the increasing share of trade by foreigners on the TSE.

48. The number of foreign companies listed on the TSE decreased from 125 at the end of 1991 to 97 in mid-1994. Since 1993, several Chinese, Korean, and Indonesian companies have chosen to be listed on the NYSE instead of the TSE. Some analysts believe that since Japanese households have a high propensity to save, Tokyo should attract firms seeking investment funds. The fact that foreign firms are delisting and choosing not to be listed is seen as evidence that Tokyo is losing its competitive edge as a major capital center.

49. This discussion summarizes the arguments of International Monetary Fund (1995, pp. 22-23) and Ito and Lin (1996). 
creases in Osaka's margin requirement were not associated with changes in volatility. ${ }^{50}$ In fact, changes in the OSE margin requirements seem to have been motivated by concern about speculative activities that apparently contributed to the decline in the level of stock indexes (both cash and futures). It was suspected that speculation in the futures market and futures-cash arbitrage had caused the sharp decline in the cash market. In 1991, with stock prices declining, the Japanese regulatory agencies became concerned about a further fall in prices and adopted several measures to raise the costs of transactions in the cash and futures markets, including increasing the margin requirement. ${ }^{51}$

Nevertheless, raising the margin requirement clearly cost the OSE business. ${ }^{52}$ The financial industry is commonly thought to be a growth industry. If regulations are too restrictive and the costs of transactions are too high, the industry will be stifled and businesses driven away to exchanges abroad. Although not conclusive, there is some evidence that the collapse of the bubble (specifically, declining stock prices) forced the imposition of tighter regulations and higher costs, contributing to the decline in the volume of business on the Japanese exchanges. The volume of transactions in Euro yen interest rate futures on SIMEX was only 5.6 percent of the volume on the TIFFE in 1990, but had grown to 26.7 percent in the first half of 1996. Alarmed by this development, the TIFFE plans to increase trading by one hour, effective November 1996.

\section{Distribution}

The Japanese distribution system is often blamed for its inefficiency and for causing high retail prices. In vertical keiretsu, distributors do not allow the goods of rival manufacturers to be distributed to group retailers. Multilayer wholesalers stifle efficiency. And the system in-

50. See Ito and Lin (1996).

51. Regulations on cash markets and futures market were tightened four times between August 1990 and December 1991. In addition to raising margins, the authorities narrowed the trigger for a circuit breaker and increased the period of time out after a circuit breaker had been activated. Additional measures adopted in February and June 1992 forced large traders to disclose their positions and trading records on futures and options.

52. See Ito and Lin (1996). 
cludes many small-scale retailers who cannot realize economies of scale. ${ }^{53}$ Distribution was a source of trade conflict between Japan and the United States, especially during the negotiations for the Structural Impediments Initiative (SII) in 1989-90. The United States argued that the fact that Japan has few large-scale retail stores, which tend to carry more imported goods than smaller stores, hurts firms seeking to export to Japan. Critics pointed, in particular, to Japan's large-scale retail store law, which restricted the network expansion of department stores, discount stores, and retail franchises.

Under that law as it stood in 1991, the construction of a large-scale retail store had to be approved by a specially designated local council, and the council would not do so without the consent of small stores in the immediate vicinity of the site. Since smaller family stores are typically afraid of competition from large stores, the council did not give its permission easily. In addition, the council had authority to impose conditions on the proposed store in four respects: date of opening; number of annual holidays (no store can operate 365 days a year); hours of business (no store can operate 24 hours a day; typically, a large store had to close by 7 p.m.); and floor space.

Partly as a result of the pressure from the United States at the SII talks, the Japanese government modified the approval procedure for the construction of large-scale retail stores in 1991 and revised the law accordingly in 1992. The council was abolished, and the procedure was greatly simplified. The number of large-scale retail stores has been growing since 1992, despite the fact that the total value of retail sales was declining in the aftermath of the bubble.$^{54}$ Competition at the retail level has helped to prevent retail prices from rising, and sometimes even to lower them. Since new stores, especially discount stores, are not sampled in the consumer price survey, it is likely that the consumer price index, the rate of increase of which declined from 1.6 percent in 1992 to -0.1 percent in 1995 , has in fact been biased upward in recent years. Large-scale retail stores are finally becoming popular in the

53. For details and statistics, see Ito (1992, ch. 13).

54. Average sales of large-scale retail stores were increasing by 6 to 7 percent from 1988 to 1990 . The annual growth rate of sales dropped to 4 percent in 1991 and then became negative: -2 percent in 1992, -5 percent in 1993, and -2 percent in 1994 and 1995. It is expected to be positive in 1996. 
suburban communities of metropolitan cities in Japan, although it will take some time for them to become as common as those in the United States. ${ }^{55}$

\section{Agriculture and Land Use}

Although prices in Tokyo are almost universally higher than those in New York or London, housing costs (both the purchase price of housing and rents) probably present the most striking comparison. As a result of the higher housing costs, the floor space available to a typical family is much smaller in Japan. Many of the problems that contribute to higher housing prices have been identified, including excessive protection of tenant rights, restrictive zoning laws and restriction on building heights, high capital gains taxes on housing, and the bequest taxation system. ${ }^{56}$ During the period of the bubble, the government effectively increased the capital gains tax by suspending the carry-over of capital gains of owner-occupied residential properties and increasing the tax rate on short-term holdings. It also introduced a system for approving land transactions and imposed price ceilings. And it restricted the sale of government land, especially from the formerly national railways. All of the measures were ostensibly taken to discourage speculation. However, they also restricted the supply of land, discouraged transactions, and made the market thin. After the bubble had collapsed, the price ceilings were effectively lifted, and the sale of government land was permitted again. The high rate of capital gains taxation on real estate remains, however.

One important constraint on supply that contributes to high land prices is the continued existence of plots of agricultural land in prime suburban areas of Tokyo and other metropolitan cities. In terms of the allocation of resources, this makes no sense. It has been argued that these anomalies have been preserved because real estate and bequest taxes on agricultural land are low, even under residential zoning. In 1991 the law was revised to restrict the definition of agricultural land for the purposes of real estate and bequest taxation under residential

55. Admittedly, the difficulties of opening a large-scale retail store and the restrictions on days and hours of operation in Japan are probably comparable to those in France and Germany.

56. See Ito (1992, pp. 421-26). 
and commercial zoning. Basically, once land is designated as agricultural, neither the present owner nor his beneficiaries can change the designation without penalty. This revision has forced the conversion of some land, but the rest is virtually locked in as agricultural land. After the revision went into effect, about one-third of the agricultural land plots in the Tokyo area were confirmed as such, while two-thirds were taxed as residential and commercial land. It remains to be seen whether the change in the law will force enough urban "agricultural" land onto the residential and commercial land markets to lower overall land prices. One issue that deserves more debate is the high capital gains tax on real estate that, on one hand, alleviates income inequity arising from windfalls to land owners, but on the other, prolongs the inefficient use of land.

\section{The East Asian Miracle}

The increase in trend growth rates among the East Asian economies during the past two decades is reminiscent of the Japanese experience in the 1950s and 1960s. So, too, are the rapid structural changes in industry, and several social and economic indicators. How similar have the experiences of East Asia and Japan actually been? This section describes economic development in East Asia and draws parallels with the Japanese experience. First, it identifies characteristics that are common to the successful Asian countries. Second, it discusses similarities and differences among the East Asian countries and between East Asian countries and Japan. Third, it offers lessons from the Japanese experience for East Asian economies that are rapidly approaching a level of development at which they might be vulnerable to the difficulties that Japan has faced since the mid-1980s.

\section{Growth}

The four most prominent East Asian economies-Korea, Taiwan, Hong Kong, and Singapore-started to grow rapidly in the mid-1970s, and others-Thailand, Indonesia, and Malaysia-followed suit in the 1980s. China started to grow fast in the late 1980s. Figure 5 plots the ratio of per capita GDP for East Asian countries (converted to the dollar 
Figure 5. Relative Per Capita GDP, Selected East Asian Countries, 1950-92a

Share of U.S. GDP

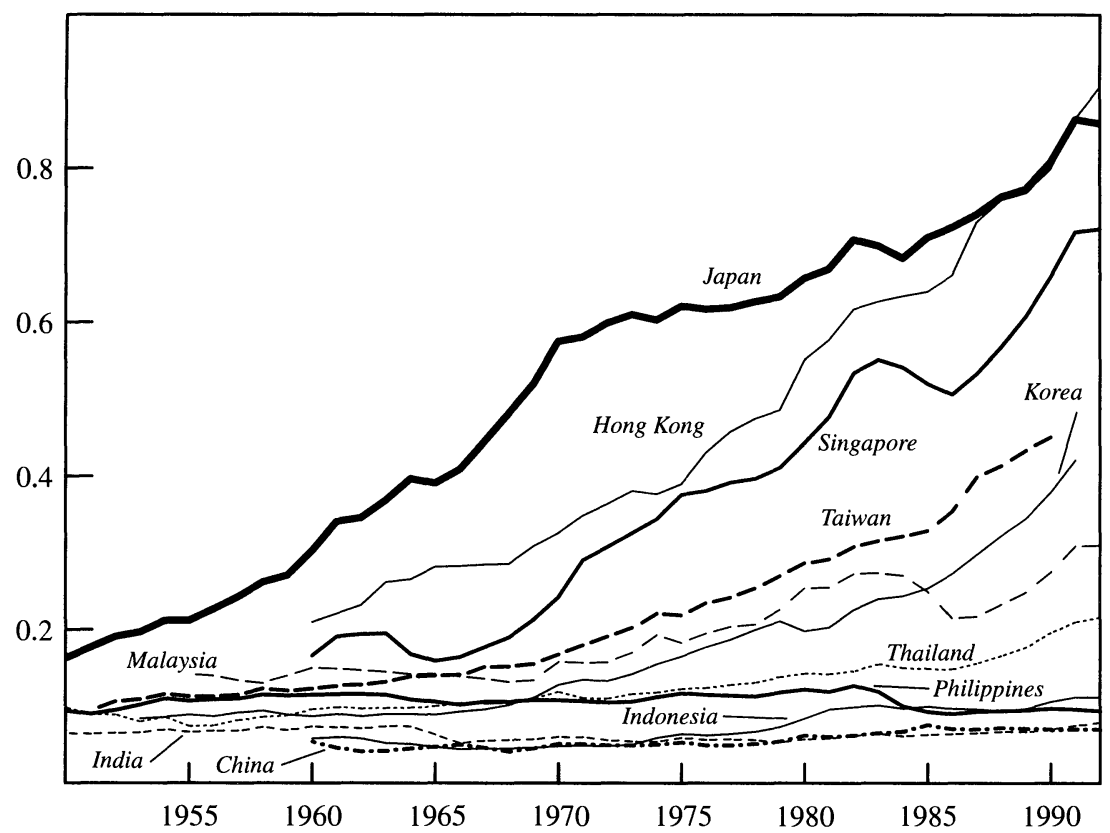

Source: Data on nominal per capita GDP for the East Asian countries are from International Monetary Fund, International Financial Statistics (September 1996) (available on CD-ROM); and for the United States, from the Economic Report of the President, 1996. All values are converted into U.S. dollars by using the purchasing power parity exchange rates found in the Penn-World Tables, Mark 5.6, available from the worldwide web page of the National Bureau of Economic Research.

a. Sample periods vary.

using the purchasing power parity exchange rates found in the PennWorld Tables) to U.S. per capita GDP. It shows how, one after another, these economies took off and narrowed the gap with the United States. It is clear that the levels of per capita income converge.

The growth experience of these economies is reminiscent of Japan's experience a decade earlier, also shown in the figure. In all of these cases, at some point in time the economy starts to grow very fast (that is, at an annual rate exceeding 7 percent) and it maintains that level of growth for a decade or more. Japan followed this path in the 1950s and 1960s; Korea, Hong Kong, Taiwan, and Singapore did so in the 1980s; and Malaysia, Thailand, Indonesia, and China seem to be doing so today. 
Table 4. Share of Agriculture in GDP, Selected East Asian Countries, ${ }^{a}$ Postwar Period

\begin{tabular}{lccccccc}
\hline \multirow{2}{*}{$\begin{array}{l}\text { Threshold } \\
\text { share }\end{array}$} & \multicolumn{5}{c}{ Year in which agriculture fell below threshold share of total production } \\
\cline { 2 - 8 } & Japan $^{\mathrm{b}}$ & Korea & Thailand & Malaysia $^{\mathrm{c}}$ & Indonesia & China & Philippines \\
\hline 30 percent & $\ldots$ & 1967 & 1967 & 1964 & 1976 & 1984 & Before 1960 \\
20 percent & 1956 & 1978 & 1982 & 1983 & 1991 & 1992 & $\ldots$ \\
10 percent & 1963 & 1989 & 1988 & $\ldots$ & $\ldots$ & $\ldots$ & $\ldots$ \\
\hline
\end{tabular}

Source: The World Bank's CD-ROM World Data 1995 and, for Japan before 1960, Ohkawa and Shinohara (1979).

a. Each country experienced a secular decline in the production share of agriculture over the sample period. Hong Kong and Singapore are not included because agriculture's share has never been above 10 percent in either country.

b. Japan's agriculture share has been below 30 percent throughout the postwar period.

c. Data on Malaysia are not available after 1984.

d. In the Philippines, agriculture's share has been between 20 and 30 percent since 1960, when data become available.

Both the sudden increase in rates of growth and the geographical proximity of these countries caught the attention of economists. Many have investigated the possible causes of such rapid growth in this particular set of countries during this period. Cross-country regressions of growth rates as a function of initial conditions, such as economic and social variables in a base year, typically fail to predict the exceptional performance of the East Asian economies. ${ }^{57}$ In this light, their high growth rates are miraculous. However, there are insights to be gained from the important similarities and differences that appear among the high-performing East Asian economies, as well as between each of these and Japan.

\section{Structural Changes in Industry}

As was the case in Japan, the East Asian economies experienced rapid structural changes in industry and exports. For countries without significant resources, like most East Asian economies, including Japan and Korea, successful growth requires industrialization, which enables them to produce and export more of the manufactured goods that are in demand in world markets. Hence changes in agricultural and industrial output shares can serve as benchmarks of economic development.

Table 4 shows how selected economies have reduced the shares of their agricultural sectors in GDP over the past thirty years, by indicating the year in which that share fell below various thresholds. (For example, in Korea the ratio of agriculture to output fell below 20 percent in 1978.) The decline in agriculture seems to be a good indicator of in-

57. See, for example, Easterly (1995) and Barro and Sala-i-Martin (1995). 
dustrialization and rapid growth. The notable exceptions are Hong Kong and Singapore, which have never had substantial agricultural sectors. These economies started as commercial entrepots and then became producers themselves. Their transformation was from commerce to manufacturing.

The changing product composition of exports is another marker of rapid growth. Typically, countries that had traditionally exported primary commodities shifted, first, to exporting textiles and simple (light) industrial products. In the next stage, production and exports shifted to more sophisticated goods, such as machinery, steel, and automobiles. ${ }^{58}$ Table 5 shows the share of machinery in exports for selected countries. Machinery exceeded 30 percent of exports in 1983 in Korea and Singapore, in 1987 in Taiwan, and in 1989 in Malaysia. Again Hong Kong stands out: its machinery share crossed 20 percent in 1979, but has never risen to the next level. The patterns in output and export imply that these East Asian economies (excepting Hong Kong) are repeating Japan's pattern of economic development.

\section{Balassa-Samuelson in East Asia}

The experience of the East Asian economies and Japan can be viewed against predictions about growth and real exchange rates based on the Balassa-Samuelson model. If productivity growth is faster in tradable sectors (mainly manufacturing) than in nontradables, the price of man-

58. This pattern of industrial sequencing is sometimes called the flying geese pattern, after the shapes of the time series for imports, domestic production, and exports of a given commodity. First, the commodity is imported (imports rise); then, as domestic industry becomes competitive, possibly as a result of government targeting, domestic production of the commodity begins (imports decline, domestic production rises); subsequently, domestic production exceeds domestic consumption, and the country becomes a net exporter of the commodity (exports rise); however, when goverment policy shifts to target another industry, domestic production falls (domestic production and exports decline). For an example of such a graph, see Ito (1992, p. 26). This idea was first developed by Akamatsu (1961); for a summary of the subsequent literature, see Ohkawa and Kohama (1989; p. 12). In the recent Japanese literature, the flying geese pattern characterizes the "vertical division of labor" that is developing in the region as other East Asian economies follow Japan's pattern of industrial development: the most advanced nation in the region (Japan) exports sophisticated parts, goods, and services; middle-income countries engage in assembly of sophisticated products or mass production of less sophisticated products; and low-income countries engage in highly laborintensive production. The validity and universality of this hypothesis have not been rigorously tested. 
Table 5. Share of Machinery in Exports, Selected East Asian Countries, ${ }^{a}$ Postwar Period

\begin{tabular}{lccccccc}
\hline & \multicolumn{6}{c}{ Year in which machinery rose above threshold share of total exports } \\
\cline { 2 - 7 } $\begin{array}{l}\text { Threshold } \\
\text { share }\end{array}$ & & & & & \multicolumn{4}{c}{ Hong } \\
\hline Japan & Singapore & Korea & Taiwan & Malaysia & Kong & Thailand \\
30 percent & $\ldots$ & 1973 & 1978 & 1973 & 1986 & 1979 & 1991 \\
40 percent & $\ldots$ & 1983 & 1983 & 1987 & 1989 & $\ldots$ & $\ldots$ \\
50 percent & 1969 & 1985 & 1992 & 1992 & $\ldots$ & $\ldots$ & $\ldots$ \\
60 percent & 1984 & 1992 & $\ldots$ & $\ldots$ & $\ldots$ & $\ldots$ & $\ldots$ \\
\hline
\end{tabular}

Source: The World Bank's CD-ROM World Data 1995.

a. Indonesia and the Philippines are not included because the export share of machinery has never risen above 20 percent in either country.

b. Japan's machinery share has been above 30 percent throughout the postwar period.

ufactured output will fall relative to a broad index like the CPI. Since manufacturing productivity growth is especially rapid in the highgrowth economies, as nominal exchange rates respond to tradables prices, the real exchange rate (measured as the nominal rate adjusted by CPIs) will appreciate. Under these conditions, rapid growth will be correlated with real exchange rates. ${ }^{59}$ Figure 6 shows the relationship between growth and the real exchange rate for the East Asian countries in 1980-95, and also for Japan during its period of rapid growth, 1965-80. The newly industrializing economies (NIEs)—Korea, Taiwan, Singapore, and Hong Kong-do exhibit the Balassa-Samuelson effect. But others do not.

Moreover, analysis of the behavior of tradables and nontradables prices in these economies yields several interesting findings. ${ }^{60}$ Two, in particular, are noted here. First, in some of the economies that do not follow the Balassa-Samuelson path, the price of nontradables relative to tradables does not clearly increase over time. Singapore is a promi-

59. Sachs and Warner (1995b) and Sachs (1996) emphasize the importance of the resource allocation in development. If a country is endowed with natural resources, as many Latin American countries are, then its comparative advantage will lead the country to specialize in agriculture and it will experience slow growth. But if a country is not endowed with natural resources, as is often the case in East Asia, manufacturing exportled growth may result. In the latter instance, prices of nontradables tend to increase relative to those of tradables, because resources are concentrated in manufacturing, and the real exchange rate appreciates. Sachs and Warner (1995a) find that "openness," which to some extent serves as a proxy for economic reform in general, is a key indicator of rapid economic development.

60. See Ito and others (1996). 
Figure 6. Real Exchange Rate Changes and Growth Relative to the United States, Selected East Asian Countries, 1980-95

Annual real exchange rate change (percent) ${ }^{\mathrm{a}}$

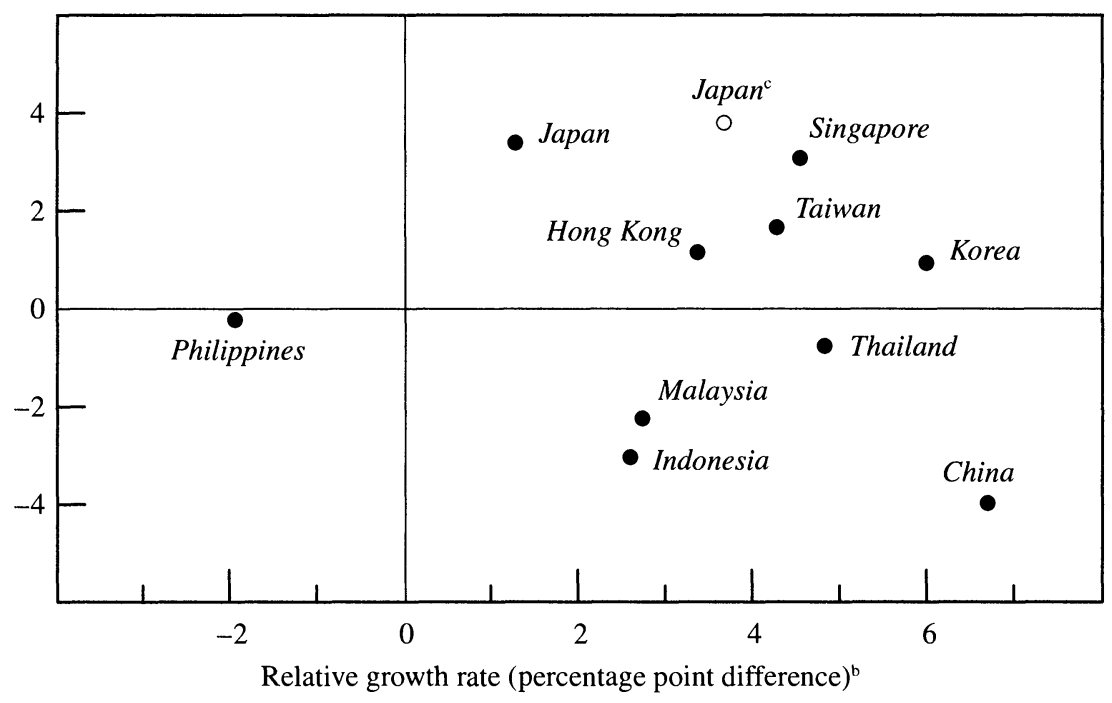

Source: Author's calculations. Data on GDP for the United States are from the Economic Report of the President, 1996. GDP and nominal exchange rate data for East Asian countries and CPI data for all countries (used to calculate real exchange rates) are from International Monetary Fund, International Financial Statistics (September 1996) (available on CD-ROM).

a. Calculated as $100 \times$ average annual change in the natural $\log$ of an index that is constructed so that $1990=1$.

b. Per capita GDP growth rate: given country less United States.

c. $1965-80$.

nent example. In these countries, sectors that are classified as nontradable are, in fact, efficient and experience productivity growth. Second, there is a drift in tradables prices denominated in a common currency, suggesting that the law of one price for tradables does not hold for many countries. In Japan and Singapore, for example, prices of tradables steadily increased relative to those of their trading partners. If technological advance is achieved not by expanding the volume of production but by making higher quality products, the change in quality will not be captured in the usual statistics. Therefore this effect will not be picked up by the Balassa-Samuelson hypothesis using aggregate data.

Real exchange rate movement can vary for different stages of development in a given country. As noted above, Japan's real exchange rate actually fell when the growth rate picked up in the 1930s. The very early stages of the transition from an agricultural to a manufacturing 
economy may require a moderate real depreciation. If a developing country's manufacturing sector is not as sophisticated as those of the leading countries, a depreciation of its currency can boost sales and output, thus helping the economy. Once Japan's manufacturing industries had reached the technological level of the leading economies and achieved a certain share of the world market, further technological progress increased the quality of products, rather than the volume. If such effects in progressive stages of development are universal, some of the East Asian countries that have recently experienced high growth may soon experience real appreciation of the currency.

\section{A Model for Development in East Asia}

The geographical and cultural proximity of the successful East Asian economies inevitably raises hopes that identifying common charcteristics will yield a formula for growth. High saving, high investment, and export promotion are the characteristics most often cited in this context. At first glance, Japan and the NIEs do share many common traits. They are poor in natural resources and densely populated. They share a Confucian tradition. Their populations are highly educated and saving rates are high. Exports have served as the engine for increased growth. And in all except Hong Kong, the government has intervened in the market to help industrialization, leading many economists to observe that the NIEs are emulating Japan's industrial policy.

However, these economies have many distinctive features as well as similarities. For example, while Korea's industrial structure is dominated by large industrial conglomerates (the Korean chaebol is similar to the Japanese keiretsu), in Taiwan, small businesses predominate. Japan did not rely on foreign capital for investment, whereas Korea borrowed so heavily from abroad that, in the early 1980s, it was one of the most indebted countries, though by the end of the decade it had managed to reduce its liability through growth and current account surpluses. Financial institutions in Taiwan are government owned, while in Korea financial institutions are private and have strong connections with large companies in the chaebol.

I now look more closely at both similarities and differences, and 
then suggest how the East Asian experience may be understood in the framework of development economics and the new growth theory.

\section{Similarities among East Asian Countries}

As emphasized above, the patterns of industrial structural changes, manifested in output shares of different sectors and in exports, seem to suggest some similarities in the process of industrialization. First, increases in the share of exports in GDP and increases in the investment rate are common to the successful East Asian economies. Since growth comes from capital-intensive industries, a high investment rate is almost axiomatic. The prominence of exports is examined below. High investment must be accompanied by high domestic saving, unless foreign capital comes in to fill the gap. Capital inflows (or equivalently, current account deficits) must be carefully managed so that they do not trigger sudden outflows of capital.

Another strength of the successful East Asian economies is their high levels of human capital. Casual observation and the few internationally standardized tests that exist suggest that the school systems of Korea and Singapore, as well as Japan, are producing students with better basic skills for the same number of years of education than those in the United States. In addition, macroeconomic stability, marked by low inflation and low government deficits, political stability, and a relatively equal income distribution, have all contributed to growth in East Asia.

\section{Export Promotion}

In all of the high-growth economies of East Asia, the volume of exports has grown rapidly and the composition of exports has changed significantly over a short period. ${ }^{61}$ The East Asian success in exports is not just a market outcome of industrialization, but the result of government promotion. The Japanese experience in export promotion has been studied extensively, as has experience in East Asia, Korea, Taiwan, and Singapore, where export promotion policies targeted certain industries. ${ }^{62}$

61. In fact, the World Bank identifies exports as the key to the success of the East Asian economies (World Bank, 1993).

62. For example, on export promotion in Japan, see Itoh and others (1988), Ito (1992; ch. 7), and Komiya, Okuno, and Suzumura (1984); and on the East Asian countries, see Amsden (1989), Noland (1990), Young (1992), and Westphal (1990). 
In Korea, thirteen items, including silk, cotton, radios, and electrical goods, were targeted as exports in 1965, and the list was later expanded. Over the next three decades, the composition of exports changed radically, from simple manufactured goods to heavy goods and electronics. Targeted industries received direct tax incentives and subsidies, as well as policy loans. It is estimated that these direct and indirect subsidies were large enough to cancel out the adverse effect of currency overvaluation in the late 1960s. ${ }^{63}$ Targets for export values were set for each commodity and export activity was closely monitored by the government. Achievement in exporting was rewarded by further incentives.

Taiwan successfully implemented an export-oriented industrial policy only after its import substitution program had failed in the 1950s. From the 1960 s, the government introduced measures to promote exports and target industries, including free-trade zones, preferential loans, tax exemptions, and tax holidays. Although some import protection was maintained until the mid-1980s, the list of items remained short. Banks are state owned and provide capital to serve policy objectives.

Singapore also tried import substitution, in the 1960s, and its failure led to policy reform that stressed exports. The Development Bank of Singapore provided loans to targeted companies and held their shares, with emphasis on the electrical machinery and petroleum products industries. ${ }^{64}$ Singapore, in contrast to Korea, also encouraged inward foreign direct investment. Moreover, the government refrained from regulating the behavior of multinational firms in such matters as the repatriation of profits and local content of products. Tax incentives, such as tax holidays, were introduced in 1967. Foreign firms (those with more than 50 percent foreign equity) accounted for 82 percent of Singapore's manufacturing exports in 1984.

The East Asian countries reviewed here succeeded at rapid economic growth mainly as a result of expanding exports. This is not surprising. An industry with large economies of scale must expand into foreign

63. Westphal (1990) estimates that benefits amounted to more than 8 percent of total merchandise exports, while currency was overvalued by about 9 percent. Hence he argues that, except in infant industries, exports were encouraged through "neutral", policies, in that they were characterized by "the absence of differential effects on the allocation of resources among activities relative to the putative circumstances of perfectly free trade"' (p. 45).

64. See Young (1992). 
markets if domestic markets are small. And a resource-poor country must develop industries that can produce successful exports, in order to finance its growing needs for imports without incurring too much debt. To this end, it is desirable to choose products with high income elasticities, so that exports will grow with the incomes of the importing countries, and to technologically upgrade exporting industries.

One reason for the success of export promotion, as opposed to import substitution or other types of industrial policy, is related to product quality. ${ }^{65}$ In any government intervention, monitoring quality is a difficult task. Without competition or judgment in the market, it is hard to evaluate the efforts of producers. The quality of exports is judged abroad. In the case of import substitution, domestic consumers and users are captive customers and producers may not have incentives to improve quality. Admittedly, there are both theoretical and empirical grounds for criticizing export promotion. Vested interests could take control of the initiative, and the wrong industries could be targeted. Ultimately, its success should be compared to that of an alternative policy. In this light, it seems difficult to argue that industrialization in Korea, Taiwan, or Singapore could have been better without export promotion.

Deciding which industries to promote might seem a serious problem. However, it is not difficult for a developing country to pick an industry that is losing competitiveness in countries that are slightly further along in terms of economic development but have similar factor endowments and economic environments. Regional development, whether in nineteenth century Europe or in Asia in the 1980s, benefits from market pressure and lessons learned from neighboring countries.

\section{Differences among East Asian Countries}

Although there are abundant similarities in economic structure and industrial policy between East Asian countries, there are also some major differences. For example, unlike Japan, many Asian countries were not successful at targeting industries for import substitution. Moreover, patterns of development (such as changes in the industrial structure or the composition of exports) in Hong Kong and Singapore differ from those in Japan, Korea, and Taiwan. And some East Asian

65. See World Bank (1993). 
countries seem to have skipped various stages of the industrial sequencing that was common to Japan and Korea. Malaysia and Singapore succeeded in attracting foreign firms with high technology without developing textiles or light industries.

In addition, different countries have financed growth in different ways. Although Singapore and Malaysia have high saving rates to support their high rates of investment, at times other countries have achieved high investment rates by borrowing from abroad. In the 1950s, when Japan was investing in its manufacturing sectors, it had neither international capital markets nor institutional investors to draw on. Instead, Japan relied on domestic saving to supply funds for investment. By contrast, in the 1980s and 1990s growth can be financed through foreign direct investment and borrowing from abroad, thus making it possible to accelerate the process. This has substantially altered the dynamics of financing growth. On the one hand, emerging market economies have the option of borrowing from abroad to finance domestic investment; but on the other, they will face financial difficulties if their external debts become too large. External debts eventually have to be repaid, or at least stabilized as a share of GDP, if not at an absolute level. Japan's experience with promoting domestic saving may not be a precondition for growth. Thailand has a low saving rate despite its high investment rate. And Korea, as noted above, had one of the highest external debt ratios in East Asia in the early 1980s.

Furthermore, while in Korea and Taiwan the manufacturing sectors have become strong, as they did earlier in Japan, the strengths of Hong Kong and Singapore lie in their efficient and competitive financial sectors. Theoretical and empirical analyses have typically treated financial services as nontradables. Given that Singapore and Hong Kong have grown as a result of their roles as the financial centers of Asia, this categorization may not be correct. The volume of financial transactions, including foreign exchange and futures contracts, has grown faster in these markets than in most others in the world: Singapore and Hong Kong rank fourth and fifth, respectively, in foreign exchange turnover, after the United Kingdom, the United States, and Japan, according to the 1995 triennial survey of the Bank for International Settlements. ${ }^{66}$ Finally, in economies with less efficient securities markets, such as

66. Bank for International Settlements (1996). 
Japan, banks are the main intermediaries, whereas other economies, such as Malaysia, have highly active stock markets.

These differences have two interesting implications. First, some of these economies, especially those that develop strong and competitive service, distribution, and transport sectors, may not experience the real appreciation suggested by the traditional Balassa-Samuelson-type model. Second, Singapore and Hong Kong, possibly to be followed by Korea and Taiwan, may overtake Japan in the transformation to a highly productive service economy. Although the Japanese manufacturing system has been, and still is, widely regarded as efficient at turning out high-quality, innovative products, the service sector, broadly defined, is hardly cost effective or innovative.

\section{Lessons from Japan}

The lesson of the Japanese experiences for the growing East Asian countries is two fold. First, the century of Japanese economic development starting from the 1860 s, and especially the period from the 1950s through the mid-1980s, is generally regarded as a success and has some positive lessons to offer. Second, Japan's experiences over the past ten years - that is, the bubble in the second half of the 1980s and its collapse and the subsequent slow recovery in the first half of the 1990s - offer some negative lessons.

Many of the positive lessons relate to the general characteristics that made it possible for the Japanese economy to catch up so rapidly with the leading industrial countries in the 1950s and 1960s. These include several features of the long-term contracts that facilitated quality controls and innovation in manufactured goods and the excellent education system. Japan's industrial policy is more controversial. In this context, it should be remembered that Japan started with a largely planned economy at the end of World War II, and has consistently reduced the extent of government intervention in the economy over the postwar period. Tariffs were reduced step by step. Import quotas were expanded gradually. For example, restrictions on foreign exchange transactions, first on current account and later on capital account, were lifted one by one 
and rarely reversed ${ }^{67}$ In regard to industrial policy, although the government targeted certain industries for promotion, it gradually phased out subsidies over the years, transferring its support to others. And even in the targeted industries, several Japanese firms, sometimes one from each of the "big six" enterprise groups, competed in the domestic market so that firms felt the pressure of competition. This may explain the difference between Japan's successful experience with an import substitution strategy and unsuccessful experiences of many East Asian countries. Finally, Japan's experience suggests that when an export growth strategy is successful, the real exchange rate is likely to appreciate. When the Balassa-Samuelson effect is operative, resisting nominal exchange rate appreciation may result in serious domestic inflation, as Japan found out in 1972-73.

As for negative lessons, some East Asian economies are at a sufficiently advanced stage of development that they should fear repeating the unfortunate experience of the Japanese economy in the 1990s. At this time, deregulation and fostering competition for nontradables seem to be the key to raising living standards in Japan. Politicians and business leaders of countries that are riding high on the success of exportpromoting manufacturing sectors may find this logic hard to accept.

The recent real appreciation of the yen may reflect rapid productivity growth in tradable sectors relative to that of nontradable sectors, as has been the case throughout the rest of the postwar period. Alternatively, it could be that productivity growth in the nontradable sectors has been so slow that real appreciation occurs without exceptional productivity growth in the tradable sector. If the latter is true, as is suspected in the 1990 s, it is not welfare enhancing; that is, real appreciation in fact represents a decline in the standard of living.

Japan's experience warns that the possibility of a financial bubble increases as the economic growth rate picks up. If land supply is constrained, as it is in most East Asian countries, an increase in the demand

67. See Ito (1986) for the sequence of the deregulation of capital controls. Outflow restrictions were relaxed during periods when the yen was appreciating, and inflow restrictions were relaxed when the yen was depreciating. It took several cyclical movements of the yen, from the beginning of the 1970s to the mid-1980s, to eliminate capital controls altogether. 
for real estate will raise real estate prices. ${ }^{68}$ This can encourage speculation in land, which becomes all the easier if the financial sector is deregulated, as it generally is when the economy is developing rapidly. Therefore it is crucial to have a prudential policy that focuses on the risk of nonperforming loans. The need for such a policy is greater in an economy in which banks dominate industrial financing than one in which banks are less important. The Japanese experience with the bubble and its collapse provides financial institutions with a lesson on the importance of risk management.

68. For example, Hong Kong has experienced a rapid increase in both property prices and rents over the past decade. The price of residential property doubled between 1985 and 1989, and then tripled between 1989 and 1994. The rent index also doubled in the former period, but increased by only 70 percent in the latter. The experience of Tokyo shows that a price increase without an accompanying increase in rents is one sign of a bubble. However, Hong Kong's banks have high capital ratios and are considered to be prudent in managing risk. 


\section{Comments}

David E. Weinstein: Ito provides an extremely interesting and wellexecuted discussion of the issues facing Japan and East Asia. He paints a picture of Japan as a country whose development strategy worked for years, but is now faced with the dilemma of how to become a "normal" country; that is, not shackled by the unique features of Japanese political economy. Indeed, Ito argues that precisely the institutions that helped Japan to grow so fast are now preventing its recovery from recession. This suggests the possibility of an East Asian growth problem: how can other countries that have tried to follow Japan's pattern avoid the pitfalls of its recent experience?

Ito makes a convincing case. Many of the hallmarks of Japanese development-for example, corporate groups, industrial policy, lifetime employment, a rigid educational system that stresses memorization over creativity, and heavy regulation of nonmanufacturing sectorsseem not to make sense from a Western point of view, and yet, until relatively recently, were seen as necessary. Today they are seen as liabilities, but are proving very hard to dismantle. Japan seems imprisoned by the very system that gave it prominence. More important, Japan is faced with the question of what will it become if - and this is a big if-it does take the system apart.

The fundamental question is which aspects of the Japanese system should live on and which should be cast aside. I start with the positives. It is often argued that creativity is not stressed in Japanese education after elementary school. However, it is important also to ask how much creativity is stressed in education in the United States. The experience of most upper-middle-class children in high school is by no means the norm, and it is worth bearing in mind that for every child in an elite 
high school in the United States, there are thousands of students languishing in high schools that are abysmal by Japanese standards. Indeed, Harold Stevenson and James Stigler demonstrate compellingly that not only does the average Japanese high school student have better math and science ability than the average U.S. student, but Japanese students outperform their U.S. counterparts decile by decile, all the way to the top schools. ${ }^{1}$ While it is likely that this comparison is reversed in college and graduate school, the fact remains that for the 60 to 70 percent of children who do not go beyond secondary school, the Japanese system provides better training than does the United States. Thus, while Ito is correct to note that Japan needs to put more effort into improving its educational system, from a comparative standpoint, the United States has more cause for worry.

A similar argument can be made about lifetime employment. Ito suggests that slower Japanese growth rates will tend to reduce the ability of the lifetime employment system to pay out ever higher wages to older workers, for the same reason that the U.S. social security system is likely to run into difficulties. However, one could also make an argument for steep wage profiles and lifetime employment independent of aging effects. As Ito notes, lifetime employment stems in large part from the fact that there is very little professional training in Japan. The popular press laments the high number of lawyers in the United States relative to Japan, but as Gary Saxonhouse and Daniel Okimoto point out, this is true of most other types of professional too. ${ }^{2}$ For example, M.B.A.s and Ph.D.s are far more common in the United States than in Japan. Whereas American workers typically become highly skilled through schooling, Japanese workers rely far more heavily on their firms for training. This helps to account for the far higher degree of firm-specific training in Japan, as well as for the lifetime employment system. Despite this fundamental structural difference between Japan and the United States, which should act to preserve the system of permanent employment, the Japanese have been awaiting the collapse of the system since its inception: even in the 1960s, Japanese firms felt that it could not survive. Such worries about the future persist, but unless radical educational reforms are enacted, I am skeptical whether any changes will be important.

1. Stevenson and Stigler (1992).

2. Saxonhouse and Okimoto (1987). 
Since the Japanese are only beginning to add professional schools to their educational system, it is likely to be a long time before one sees anything like the collapse of the permanent employment system. Indeed, the aggregate statistics show that between 1980 and 1994 the average age of the Japanese male worker increased by 2.2 years and average tenure increased by 2.0 years. In fact, rates of average tenure have never been higher in Japan. Thus, despite anecdotal evidence that individual workers and firms do not want to honor their mutual commitments, rumors of the demise of lifetime employment would seem to be exaggerated.

Although certain policies may have contributed to higher saving, I am more skeptical than Ito that Japan's unique institutions have ever really helped the country, and hence I do not see that its current situation is inevitable. Consider the main bank system. Various studies find that the Japanese firms affiliated with main banks do not exhibit superior performance relative to firms that are not so blessed, regardless of whether performance is measured in productivity, growth, or profits. If this system truly benefits firms, one must ask why these benefits are not apparent in any of the conventional measures of performance. Similarly, if the system is so good, why did Japanese firms flock to foreign markets for new sources of capital finance the moment the government permitted foreign bond issuance?

Vertical groups and distributional groups (keiretsu) can also be rationalized in terms of Japanese tax rates, which confer significant benefits on small enterprises. For example, Japan's new consumption tax does not apply if purchases are made from a small retailer. This policy alone gives small retailers a 3 percent price advantage over large stores and helps to prevent the spread of large-scale discount stores. It is hard to make the case that the vast array of policies designed to help small businesses and maintain vertical groups has ever promoted efficiency in Japan.

Industrial policy also seems to have had a questionable impact on Japanese economic development. Richard Beason and I show that industrial policy has tended to draw resources out of fast growing sectors in manufacturing and into slow growing ones. ${ }^{3}$ In finance and insurance, Japanese industrial policy has created a system in which the government

3. Beason and Weinstein (1996). 
(in the form of the post office) has become the largest provider of banking and insurance services not only in the country but, probably, in the world. Regulation has further fragmented Japanese banking into a host of specialized institutions: city banks, long-term credit banks, regional banks, agricultural banks, and so forth. In telecommunications, as Ito notes, state-sanctioned monopolies have led to pricing structures in which calls are billed at large premiums over marginal cost: a far less efficient approach than the U.S. system of charging a flat rate for unlimited local calls. Transportation is hampered by trucking regulation, airline price regulation, and a taxi cartel that makes Japanese cabs phenomenally expensive by U.S. standards. And Japanese real estate law is hardly a model of efficiency. Given that over three-quarters of Japanese production takes place outside manufacturing, and that it is precisely in these sectors that one finds most of the inefficient regulations, it is not hard to argue that a lot of work lies ahead if Japan wants to continue to raise overall productivity levels.

Indeed, this sort of regulation helps to explain why the BalassaSamuelson predictions hold for the postwar period in Japan. Using data from Dale Jorgenson and Masahiro Kuroda on relative levels of total factor productivity (TFP), it is possible to track the movement of Japanese TFP relative to U.S. TFP. ${ }^{4}$ These data reveal two important phenomena. First, there was a general productivity slowdown in the nonmanufacturing sectors of both countries. Second, in relative terms, this slowdown was more pronounced in Japan. In other words, while the Japanese manufacturing sector did largely converge to U.S. productivity levels, the Japanese nonmanufacturing sector stopped converging.

The productivity evidence is consistent with the Balassa-Samuelson hypothesis, in the sense that slower productivity growth rates in nonmanufacturing sectors contributed to exchange rate appreciation. The standard version of the Balassa-Samuelson hypothesis postulates that slow growth in services is due to the fact that there is no significant difference between the initial levels of productivity in the nonmanufacturing sectors of the two countries. However, the productivity evidence suggests that there was, in fact, a large productivity gap in services in

4. Jorgenson and Kuroda (1990). 
the 1960 s, but for some reason the nontradables gap persisted, while the gap in tradables largely disappeared. The halt in convergence in nonmanufacturing is a major cause of the appreciation of the real exchange rate. One plausible explanation for the Japanese economy's convergence in manufacturing but not elsewhere is that services have been so highly regulated as to stifle innovation.

However, I am not sure how useful it is to search for BalassaSamuelson effects using the real exchange rate data presented in the paper. The Balassa-Samuelson model is constructed for a world in which one country is growing and the rest are at the steady state. In practice, these tests are usually implemented by looking at a country's real exchange rate relative to the United States. But is the United States the appropriate base country? The dollar was overvalued in the early 1980 s and depreciated dramatically over the decade. If the U.S. experience with growth rates and exchange rates is not representative of developed countries in general, it will tend to shift all of the points in one direction. Ito's evidence would have been more convincing if he had related the exchange rate performance of the East Asian economies to a representative basket of developed country currencies, rather than to the dollar alone.

Regardless of the mechanism underlying the Balassa-Samuelson effect, the larger question remains of how Japan moved from being a country that many developing countries tried to emulate to being yet another major economic power in distress. To some degree, Japan was a victim of its own success. In the 1960s, when Japan was one of the first countries to exhibit persistent double-digit growth, observers believed that this phenomenon was the result of unique institutions. However, as other countries with very different institutional structures began to replicate the Japanese growth experience, it became increasingly clear to economists that Japan's growth probably had not been due to distinctive national features.

The problem is that it has been very hard for Japanese policymakers to learn this lesson. For decades, the Japanese believed that their country's superior performance was due to its superior institutions. Only now are they learning that other economies, with different institutions, can grow at similar rates. Had Japan not grown quickly in the 1960s, it would have been bombarded with IMF and World Bank missions 
recommending that the Japanese dismantle many of the institutions that now appear inefficient. Instead, rapid growth rates gave the Japanese the hubris to believe that the normal rules of economics did not apply.

I would argue that the primary lesson that other Asian countries should learn from Japan is that hubris about economic performance can have long-term implications. This self-confidence manifests itself in many ways; for example, various Asian leaders have argued that democracy and human rights issues are less important in Asia. When a country's economy is growing by 10 percent a year, virtually all of the goverment's sins are forgivable. But when an economy is not growing, the problems seem far more clear. The key lesson from Japan seems to be: "Do not let high growth rates fool you into believing that economic reform and liberalization are unnecessary, because it will be much more painful to undertake political reforms when growth slows."

A corollary, which one can also draw from Ito's analysis, is that there does not appear to be one single model of East Asian growth. Some East Asian countries follow Confucian traditions, others are predominantly Muslim; in some, such as Singapore, the government is actively interventionist in the economy, while others, such as Hong Kong, are much closer to laissez-faire capitalism. The bottom line seems to be that economies have a wide degree of latitude in accommodating domestic culture, traditions, and institutions without sacrificing overall standards of living. The evidence suggests that, as long as countries maintain liberal trade and economic regimes, a few industrial policy warts will not tarnish the beauty of the capitalist system.

Ito also raises the difficult issues of the role of government in generating the Japanese downturn and the prognosis for the future. I think that his analysis of the role of monetary policy during the bubble is plausible, but I would like to comment on his assessment of the prognosis. First, I would caution against excessive pessimism regarding Japan. Every time the Japanese economy falters, there is a flood of arguments about why Japan no longer poses a problem. Following the oil shock of 1973, Japan's high growth era ended. The growth rate of nominal GDP per capita sank below that of the United States, and per capita GDP measured at exchange rates did not differ by much between the two countries. In light of these facts, media pundits began to pronounce the beginning of the "no problem era," when all trade friction between Japan and the United States would melt away. However, the 
1980s soon followed-a decade of tremendous U.S.-Japan trade conflict. This suggests that one should exercise caution in evaluating the current Japanese situation. While the Japanese economy is mired in recession and the U.S. economy is in the midst of one of the longest periods of continuous economic expansion in history, it is easy to think that the debate has shifted from "Japan bashing" to "Japan passing." The real test of whether there has been structural change will come when Japan recovers and the U.S. economy slips into recession. My guess is that U.S.-Japanese relations then may not look so different from those of the 1980s.

I agree with Ito that the Bank of Japan's policies have exacerbated the Japanese situation and continue to do so. The decision to maintain a tight monetary policy in the face of a financial crisis arising from a decline in prices may not be the wisest for the Japanese economy. Furthermore, many of the antirecessionary packages, such as temporary tax cuts, probably did little to stimulate the Japanese economy. And the lack of government action on the bad loans problem encouraged the uncertainty in Japanese financial markets, because financial institutions were hesitant to make new loans until they had a better picture of their own financial situations. However, it is clear that the Japanese economy will recover. The only question is whether this period of reform will stimulate new growth in nonmanufacturing sectors. 


\section{References}

$\rightarrow$ Akamatsu, Kename. 1961. "A Theory of Unbalanced Growth in the World Economy." Weltwirtschaftliches Archiv 86(2): 196-217.

Amsden, Alice H. 1989. Asia's Next Giant: South Korea and Late Industrialization. New York: Oxford University Press.

Aoki, Masahiko, and Hugh Patrick, editors. 1994. The Japanese Main Bank System: Its Relevance for Developing and Transforming Economies. New York: Oxford University Press.

Asako, Kazumi, Takatoshi Ito, and Kazunori Sakamoto. 1991. "The Rise and Fall of Deficit in Japan, 1965-1990.' Journal of the Japanese and International Economies 5(4): 451-72.

Bank for International Settlements. 1996. Central Bank Survey of Foreign Exchange Derivatives Market Activity, 1995. Basel: Bank for International Settlements.

Barro, Robert, and Xavier Sala-i-Martin. 1995. Economic Growth. New York: McGraw Hill.

Barthold, Thomas A., and Takatoshi Ito. 1992. "Bequest Taxes and Accumulation of Household Wealth: U.S.-Japan Comparison.' In The Political Economy of Tax Reform, edited by Takatoshi Ito and Anne O. Krueger. Chicago: University of Chicago Press.

Beason, Richard, and David E. Weinstein. 1996. "Growth, Economies of Scale, and Targeting in Japan (1955-1990)." Review of Economics and Statistics 78(2): 286-95.

Campos, Jose Edgardo, and Hilton L. Root. 1996. The Key to the Asian Miracle: Making Shared Growth Credible. Washington: Brookings.

Denison, Edward F., and William K. Chung. 1976a. "Economic Growth and Its Sources.' In Asia's New Giant: How the Japanese Economy Works, edited by Hugh Patrick and Henry Rosovsky. Washington: Brookings.

. 1976b. How Japan's Economy Grew So Fast: The Source of Postwar Expansion. Washington: Brookings.

Easterly, William. 1995. "Explaining Miracles: Growth Regressions Meet the Gang of Four.' In Growth Theories in Light of the East Asian Experience, edited by Takatoshi Ito and Anne O. Krueger. Chicago: University of Chicago Press.

Friedman, Milton, and Anna J. Schwartz. 1982. Monetary Trends in the United States and the United Kingdom: Their Relation to Income, Prices, and Interest Rates, 1867-1975. Chicago: University of Chicago Press.

Fujino, Shozaburo. 1975. A Neo-Keynsian Theory of Income, Prices, and Economic Growth. Tokyo: Kinokuniya.

Gibson, Michael S. 1996. "More Evidence on the Link between Bank Health 
and Investment in Japan." International Finance Discussion Paper 549. Washington: Board of Governors of the Federal Reserve System (May).

Hayashi, Fumio. 1986. “Why Is Japan's Saving Rate So Apparently High?' In NBER Macroeconomics Annual 1986, edited by Stanley Fischer. Cambridge, Mass.: MIT Press.

Hayashi, Fumio, Albert Ando, and Richard Ferris. 1988. "Life Cycle and Bequest Savings: A Study of Japanese and U.S. Households Based on Data from the 1984 NSFIE and the 1983 Survey of Consumer Finances.' Journal of the Japanese and International Economies 2(4): 450-91.

Horioka, Charles Yuji. 1990. "Why Is Japan's Household Saving Rate So High? A Literature Survey.' Journal of the Japanese and International Economies 4(1): 49-92.

Horiuchi, Akiyoshi. 1996. "An Evaluation of Japanese Financial Liberalization: A Case Study of Corporate Bond Markets."' In Financial Deregulation and Integration in East Asia, edited by Takatoshi Ito and Anne O. Krueger. Chicago: University of Chicago Press.

International Monetary Fund. 1995. International Capital Markets: Developments, Prospects, and Policy Issues. Washington: International Monetary Fund.

Ito, Takatoshi. 1986. "Capital Controls and Covered Interest Parity between the Yen and the Dollar.' Economic Studies Quarterly 37(3): 223-41.

- 1992. The Japanese Economy. Cambridge, Mass.: MIT Press.

- 1993. "The Land/Housing Problem in Japan: A Macroeconomic Approach.' Journal of the Japanese and International Economies 7(1): 1-31.

Ito, Takatoshi, and Keiko Nosse Hirono. 1993. "Efficiency of the Tokyo Housing Market.' Bank of Japan Monetary and Economic Studies 11(1): 132.

Ito, Takatoshi, and Tokuo Iwaisako. 1996. "Explaining Asset Bubbles in Japan.' Bank of Japan Monetary and Economic Studies 14(1): 143-93.

Ito, Takatoshi, and Yukinobu Kitamura. 1994. "Public Policies and Household Saving in Japan.' 'In Public Policies and Household Saving, edited by James M. Poterba. Chicago: University of Chicago Press.

Ito, Takatoshi, and Wen-Ling Lin. 1996. "Race to the Center: Competition for the Nikkei 225 Futures Trade.' Working Paper 117. Washington: International Monetary Fund (October).

Ito, Takatoshi, and others. 1996. "Exchange Rate Movements and Their Impacts on Trade and Investment in the APEC Region.' Occasional Paper 145. Washington: International Monetary Fund (December).

Itoh, Motoshige, and others. 1988. Sangyo Seisaku no Keizai Bunseki (Economic analysis of industrial policy). Tokyo: University of Tokyo Press.

Japan. Economic Planning Agency. 1995. Bukka Repoto 1994 (Prices report 1994). Tokyo: Keizai Kikakucho Bukkakyoku. 
1996. Keizai Hakusho (White paper on the economy). Tokyo: Printing Bureau, Ministry of Finance.

- Various years. Annual Report on National Accounts. Tokyo: Economic Planning Agency.

Japan. Management and Coordination Agency. 1996. Shohisha Bukka Shisuu Nenpo 1996 (Annual report on the consumer price index 1996). Tokyo: Government Printing Office.

Japan. Ministry of Health and Welfare, Institute of Population Studies. 1992. Population Projections for Japan, 1991-2090. Tokyo: Ministry of Health and Welfare, Institute of Population Studies.

Joho Tsushin Sogo Kenkyujo. 1994. Joho Tsushin Handobukku 1995 (Handbook of information and communication 1995). Tokyo: Joho Tsushin Sogo Kenkyujo.

Jorgenson, Dale W., and Masahiro Kuroda. 1990. "Productivity and International Competitiveness in Japan and the United States, 1960-1985." In Productivity Growth in Japan and the United States, edited by Charles R. Hulten. Chicago: University of Chicago Press.

Komiya, Ryutaro, Masahiro Okuno, and Kotaro Suzumura. 1984. Nihon no Sangyo Seisaku (The industrial policy of Japan). Tokyo: University of Tokyo Press.

Lawrence, Robert Z. 1993. "Japan's Different Trade Regime: An Analysis with Particular Reference to Keiretsu." Journal of Economic Perspectives 7(3): 3-19.

Levy, Jonathan, and Florence Setzer. 1991. "Broadcast Television in a Multichannel Marketplace." Working Paper 26. Washington: Federal Communication Commission, Office of Plans and Policy (June).

Noguchi, Yukio, and David A. Wise, editors. 1994. Aging in the United States and Japan: Economic Trends. Chicago: University of Chicago Press.

Noland, Marcus. 1990. Pacific Basin Developing Countries: Prospects for the Future. Washington: Institute for International Economics.

Ohkawa, Kazushi, and Hirohisa Kohama. 1989. Lectures on Developing Economies: Japan's Experience and Its Relevance. Tokyo: University of Tokyo Press.

Ohkawa, Kazushi, and Henry Rosovsky. 1973. Japanese Economic Growth: Trend Acceleration in the Twentieth Century. Stanford, Calif.: Stanford University Press.

Ohkawa, Kazushi, and Miyohei Shinohara, editors. 1979. Patterns of Japanese Economic Development: A Quantitative Appraisal. New Haven: Yale University Press.

Ohkawa, Kazushi, Nobukiyo Takamatsu, and Yuzo Yamamoto, editors. 1974. Estimates of Long-Term Economic Statistics of Japan since 1868, vol. 1, National Income. Tokyo: Toyo Keizai Shimposha. 
Ohkawa, Kazushi, and others, editors. 1966. Estimates of Long-Term Economic Statistics of Japan since 1868, vol. 8, Prices. Tokyo: Toyo Keizai Shimposha.

Okuno, Masahiro, Kotaro Suzumura, and Tsuruhiko Nanbu, editors. 1993. Nihon no denki Tsushin: Kyoso to Kisei no Keizaigaku (Electric communication in Japan). Tokyo: Nihon Keizai Shinbunsha.

Page, John M. 1994. “The East Asian Miracle: Four Lessons for Development Policy.' In NBER Macroeconomics Annual 1994, edited by Stanley Fischer and Julio J. Rotemberg. Cambridge, Mass.: MIT Press.

Patrick, Hugh, and Henry Rosovsky, editors. 1976. Asia's New Giant: How the Japanese Economy Works. Washington: Brookings.

Poterba, James M. 1994. “Introduction.” In International Comparisons of Household Saving, edited by James M. Poterba. Chicago: University of Chicago Press.

Sachs, Jeffrey D. 1996. "Resource Endowments and the Real Exchange Rate.' Paper prepared for the National Bureau of Economic Research East Asian Seminar on Economics. Hong Kong, June.

Sachs, Jeffrey D., and Andrew Warner. 1995a. "Economic Reform and the Process of Global Integration.' BPEA, 1:1995, 1-95.

- 1995b. 'Natural Resource Abundance and Economic Growth.' Working Paper 5398. Cambridge, Mass.: National Bureau of Economic Research (December).

Saxonhouse, Gary R. 1993. "What Does Japanese Trade Structure Tell Us about Japanese Trade Policy?' Journal of Economic Perspectives 7(3): 2143.

Saxonhouse, Gary R., and Daniel I. Okimoto. 1987. "The.Political Economy of Japan: Technology and the Future of the Economy.' In The Political Economy of Japan, vol. 1, The Domestic Transformation, edited by Kozo Yamamura and Yasukichi Yasuba. Stanford, Calif.: Stanford University Press.

Stevenson, Harold W., and James W. Stigler. 1992. The Learning Gap: Why Our Schools Are Failing and What We Can Learn from Japanese and Chinese Education. New York: Simon and Schuster.

Takayama, Noriyuki, and Yukinobu Kitamura. 1994. "Household Saving Behavior in Japan.' 'In International Comparisons of Household Saving, edited by James M. Poterba. Chicago: University of Chicago Press.

Toyo Keizai Shimposha. Various years. Keizai Tokei Nenkan (Economic statistics annual). Tokyo: Toyo Keizai Shimposha.

Ueda, Kazuo. 1990. “Are Japanese Stock Prices Too High?' Journal of the Japanese and International Economies 4(4): 351-70.

1993. “Japanese Monetary Policy from 1970 to 1990: Rules or Dis- 
cretion?', In Price Stabilization in the 1990s: Domestic and International Policy Requirements, edited by Kumiharu Shigehara. London: Macmillan.

Westphal, Larry E. 1990. "Industrial Policy in an Export-Propelled Economy: Lessons from South Korea's Experience.' Journal of Economic Perspectives 4(3): 41-59.

World Bank. 1993. The East Asian Miracle: Economic Growth and Public Policy. Oxford: Oxford University Press.

Yamauchi, Hirotaka, and Takatoshi Ito. 1996. “Air Transport Policy in Japan.' 'In Flying High: Liberalizing Civil Aviation in the Asia Pacific, edited by Gary Clyde Hufbauer and Christopher Findlay. Washington: Institute of International Economics.

Yamazawa, Ippei, and Yuzo Yamamoto, editors. 1979. Estimates of LongTerm Economic Statistics of Japan since 1868, vol. 14, Foreign Trade and Balance of Payments. Tokyo: Toyo Keizai Shimposha.

Young, Alwyn. 1992. "A Tale of Two Cities: Factor Accumulation and Technical Change in Hong Kong and Singapore.' In NBER Macroeconomics Annual 1992, edited by Olivier Jean Blanchard and Stanley Fischer. Cambridge, Mass.: MIT Press. 